\title{
Studies of the Zeolites
}

GEOLOGIGAL SURVEY PROFESSIONAL PAPER 504-D, E

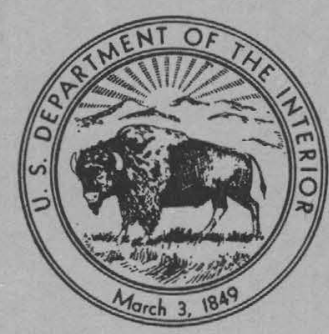





\section{Studies of the Zeolites}

Composition of Zeolites

of the Natrolite Group

and

Compositional Relations

among Thomsonites

Gonnardites, and

Natrolites

By MARGARET D. FOSTER

SHORTER CONTRIBUTIONS TO GENERAL GEOLOGY

GEOLOGICAL SURVEY PROFESSIONAL PAPER 504-D, E

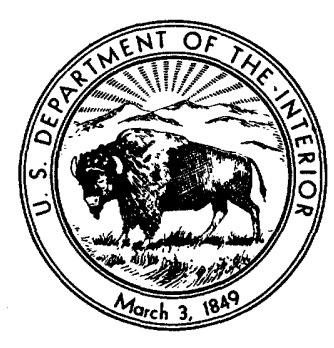

UNITED STATES GOVERNMENT PRINTING OFFICE, WASHINGTON : 1965 


\section{UNITED STATES DEPARTMENT OF THE INTERIOR \\ STEWART L. UDALL, Secretary \\ GEOLOGICAL SURVEY \\ Thomas B. Nolan, Director}

The U.S. Geological Survey Library has cataloged this publication as follows:

\section{Foster, Margaret Dorothy, 1895-}

Studies of the zeolites. D. Composition of zeolites of the natrolite group. E. Compositional relations among thomsonites, gonnardites, and natrolites. Washington, U.S. Govt. Print. Off., 1965.

v, 7 ; iii, 10 p. diagrs., tables. $30 \mathrm{~cm}$. (U.S. Geological Survey. Professional paper 504-D, E)

Shorter contributions to general geology.

Each part also has separate title page.

Includes bibliographies.

(Continued on next card)

Foster, Margaret Dorothy, 1895- Studies of the zeolites. 1965. (Card 2)

1. Zeolites. I. Title. II. Title : Composition of zeolites of the natrolite group. III. Title: Compositional relations among thomsonites, gonnardites, and natrolites. (Series)

For sale by the Superintendent of Documents, U.S. Government Printing Office

Washington, D.C. 20402 - Price 25 cents (paper cover) 


\section{Studies of the Zeolites}

\section{Composition of \\ Zeolites of the \\ Natrolite Group}

By MARGARET D. FOSTER

SHORTER CONTRIBUTIONS TO GENERAL GEOLOGY

GEOLOGICAL SURVEY PROFESSIONAL PAPER 504-D

Characteristic variations in composition of natrolites, scolecites, and mesolites, indicated by published analyses

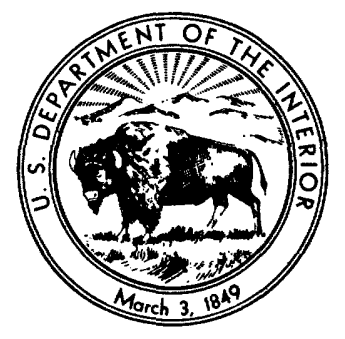




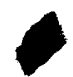




\section{CONTENTS}

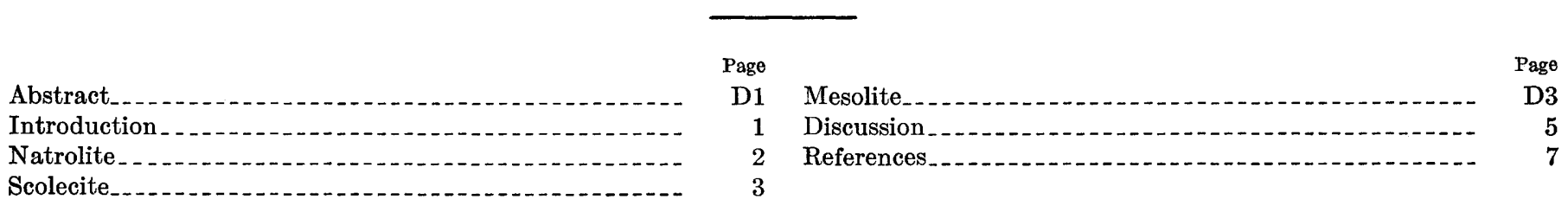

\section{ILLUSTRATION}

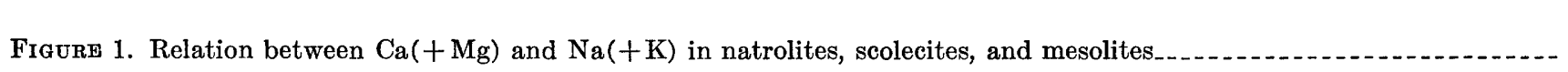

\section{TABLES}

TABLES 1-4. Analyses and calculated atomic ratios of-

1. Natrolite

2. Scolecite

3. Mesolite

4. High-Na mesolites. 


\title{
SHORTER CONTRIBUTIONS TO GENERAL GEOLOGY
}

\section{Studies of the Zeolites \\ GOMPOSITION OF ZEOLITES OF THE NATROLITE GROUP}

\author{
By Margaret D. Foster
}

\begin{abstract}
A study of the analytical data on members of the natrolite group of fibrous zeolites-natrolite, scolecite, and mesoliteindicates that the scolecites are most constant in composition, with little substitution of $\mathrm{Mg}, \mathrm{Na}$, or $\mathrm{K}$ for $\mathrm{Ca}$, and with little deviation from the theoretical value in the atomic ratios for $\mathrm{Ca}, \mathrm{Al}$, and $\mathrm{Si}$ or in the molecular ratios for $\mathrm{H}_{2} \mathrm{O}$. In many natrolites the atomic ratio for $\mathrm{Na}$, or even $(\mathrm{Na}+\mathrm{K})$, is significantly less than theoretically required, and there is often not sufficient $\mathrm{Ca}$ present to compensate for the low $\mathrm{Na}$. In some natrolites there is some evidence of replacement of $\mathrm{Na}$, either by $\mathrm{Ca}$ or by $\mathrm{CaAl}$; the $\mathrm{CaAl}$ also replaces an equivalent amount of $\mathrm{Si}$. In others the deficiency in $\mathrm{Na}$ or $(\mathrm{Na}+\mathrm{K})$ cannot be accounted for in these ways. Water is generally close to the theoretical value, despite the low $\mathrm{Na}$ contents. There is some evidence that even small amounts of $\mathrm{Ca}$ tend to increase the $\mathrm{H}_{2} \mathrm{O}$ content.

The mesolites vary widely in $\mathrm{Ca}$ and $\mathrm{Na}$ content, but threefourths of the analyses studied are characterized by uniform and nearly theoretical $\mathrm{Ca}$ content and by variable $\mathrm{Na}$ content, which ranges from the theoretical to considerably lower than theoretical value. The nearly theoretical $\mathrm{Ca}, \mathrm{Al}$, and $\mathrm{Si}$ contents of these mesolites preclude either $\mathrm{CaAl} \rightleftharpoons \mathrm{NaSi}$ or $\mathrm{Ca} \rightleftharpoons \mathrm{Na}_{2}$ types of substitution to explain the low Na contents.

The very high $\mathrm{H}_{2} \mathrm{O}$ molecular ratios of several of the low $\mathrm{Na}$ natrolites and mesolites may be due to adsorbed $\mathrm{H}_{2} \mathrm{O}$ or to hydronium ion whose presence would compensate for the low Na contents.
\end{abstract}

\section{INTRODUCTION}

Formulas for zeolites of the natrolite group-natrolite, scolecite, and mesolite-suggest minerals of fixed composition. From his study of these minerals Hey (1932, 1933, 1936) concluded that this is true with respect to the ratio $\mathrm{Si} / \mathrm{Al}$, which is quite constant, and does not deviate notably from 1.5 , but that there is more variation in their content of alkalies and alkaline earths. Most natrolites contain minor amounts of $K$ and $\mathrm{Ca}$; some scolecites contain minor amounts of $\mathrm{Na}$ and $\mathrm{K}$; and many mesolites contain more or less $\mathrm{Ca}$ or $\mathrm{Na}$ than required by the formula. $\mathrm{He}$ found no evidence of $\mathrm{NaSi} \rightleftharpoons \mathrm{CaAl}$ substitution, but attributed deviation in $\mathrm{Na}$ or $\mathrm{Ca}$ content to replacement of the $\mathrm{Na}_{2} \rightleftharpoons \mathrm{Ca}$ type. However, a casual inspection of the atomic ratios of the analyses he published does not corroborate these conclusions as to replacement.

Structural studies have indicated a definite relation and close association between the cations and the water molecules. Detailed study of the natrolite structure by Meier (1960) has shown that each $\mathrm{Na}$ ion is surrounded by 6 oxygens ( 4 oxygen ions and 2 water molecules), and each $\mathrm{H}_{2} \mathrm{O}$ molecule is close to $2 \mathrm{Na}$ ions. This relation is expressed in the $1: 1$ ratio between $\mathrm{Na}$ ions and $\mathrm{H}_{2} \mathrm{O}$ molecules. Scolecite is closely related crystallographically to natrolite and the chemical composition is similar except that the $2 \mathrm{Na}$ ions and $2 \mathrm{H}_{2} \mathrm{O}$ molecules in natrolite are replaced by $1 \mathrm{Ca}$ ion and $3 \mathrm{H}_{2} \mathrm{O}$ molecules in scolecite. The mesolite formula corresponds compositionally to 1 molecule of natrolite plus 2 molecules of scolecite, and the ratio of cations to water molecules is equivalent to $1: 1$ for the $\mathrm{Na}$ cations plus 1:3 for the $\mathrm{Ca}$ ions. Because of the close structural association between the cations and the water molecules, it would be expected that replacement of one cation by another or deficiency in cationic content would be reflected in $\mathrm{H}_{2} \mathrm{O}$ content.

It seemed desirable, therefore, to reexamine analyses of these zeolites to learn the kind and extent of variation in composition, and the relation between variation in composition and $\mathrm{H}_{2} \mathrm{O}$ content.

The analyses used in this study were carefully selected from the literature, particularly with respect to age, summation of constituents, and summation of the atomic ratios of the tetrahedral constituents. Analyses included in the study were restricted to those made since 1900, except where especially noted, for which the sum of the constituents was not less than 99.70 , or more than 100.50, and for which the atomic ratios for $\mathrm{Si}$ and $\mathrm{Al}$ totaled $10 \pm 0.10$. For purposes of comparsion all the atomic ratios for the analyses were calculated on the basis of 20 oxygen atoms. According to Hey's (1955) formulas, calculations so based give quarter-cell atomic ratios for natrolite and scolecite, and twelfth cell ratios for mesolite. 


\section{NATROLITE}

$\mathrm{Na}_{4.0} \mathrm{Al}_{4.0} \mathrm{Si}_{6.0} \mathrm{O}_{20} \cdot 4.0 \mathrm{H}_{2} \mathrm{O}$

The 27 analyses used to study the composition of natrolite are given in table 1 , with their atomic ratios. The $\mathrm{Na}_{2} \mathrm{O}$ content of these analyses ranges from a high of 16.73 percent to a low of 14.43 percent, or, in terms of atomic ratios, from $\mathrm{Na}_{4.11}$ to $\mathrm{Na}_{3.57} . \quad \mathrm{K}_{2} \mathrm{O}$, reported in about two-thirds of these analyses, ranges from 0.01 to 0.59 percent ( $0.10 \mathrm{~K}$ atomic ratio) except in No. 26 , which contains 1.27 percent $\mathrm{K}_{2} \mathrm{O}(0.20 \mathrm{~K}$ atomic ratio). In most of the analyses the atomic ratio for $\mathrm{Na}$ is less than the theoretical 4.00 indicated in the formula above. Even with $K$, the sum of the univalent cations $(\mathrm{Na}+\mathrm{K})$ is less than 4.00 in about three-fourths of the analyses, and is 3.85 or less in about one-half of them. In several analyses $(\mathrm{Na}+\mathrm{K})$ is less than 3.70 .

$\mathrm{CaO}$ is reported in all but six of the analyses, but the amounts reported are generally low. Only six analyses reported more than 0.75 percent $\mathrm{CaO}$ (about

TABLE 1.-Analyses of natrolite and their calculated atomic ratios [In order of decreasing $\mathrm{Na}_{2} \mathrm{O}$ content]

\begin{tabular}{|c|c|c|c|c|c|c|c|c|c|c|c|c|c|c|c|c|}
\hline \multirow{3}{*}{ No. } & \multicolumn{7}{|c|}{ Composition (percent) } & \multicolumn{8}{|c|}{ Atomic ratio } & \multirow{3}{*}{$\begin{array}{l}\text { Positive } \\
\text { charge }\end{array}$} \\
\hline & \multirow[b]{2}{*}{$\mathrm{SiO}_{2}$} & \multirow[b]{2}{*}{$\mathrm{Al}_{2} \mathrm{O}_{3}$} & \multirow[b]{2}{*}{$\mathrm{CaO}$} & \multirow[b]{2}{*}{$\mathrm{Na}_{2} \mathrm{O}$} & \multirow[b]{2}{*}{$\mathbf{K}_{2} \mathbf{O}$} & \multirow[b]{2}{*}{$\mathrm{H}_{2} \mathrm{O}$} & \multirow[b]{2}{*}{ Total } & \multirow[b]{2}{*}{$\mathrm{Si}$} & \multirow[b]{2}{*}{$\mathbf{A l}$} & \multirow[b]{2}{*}{$\mathrm{Ca}$} & \multirow[b]{2}{*}{$\mathrm{Na}$} & \multirow[b]{2}{*}{$\bar{K}$} & \multicolumn{3}{|c|}{$\mathrm{H}_{2} \mathrm{O}$} & \\
\hline & & & & & & & & & & & & & $\begin{array}{l}\text { Deter- } \\
\text { mined }\end{array}$ & $\begin{array}{l}\text { Calcu- } \\
\text { lated }\end{array}$ & $\begin{array}{c}\text { Differ- } \\
\text { ence }\end{array}$ & \\
\hline $\begin{array}{l}1 \\
2 \\
4 \\
5\end{array}$ & $\begin{array}{l}46.93 \\
47.09 \\
47.1 \\
47.40 \\
46.95\end{array}$ & $\begin{array}{l}27.02 \\
26.99 \\
27.1 \\
26.88 \\
27.06\end{array}$ & $\begin{array}{r}.05 \\
.27\end{array}$ & $\begin{array}{l}16.73 \\
16.46 \\
16.4 \\
16.25 \\
15.97\end{array}$ & $\begin{array}{c}0.01 \\
.11 \\
\end{array}$ & $\begin{array}{l}9.58 \\
9.80 \\
9.44 \\
9.67 \\
9.58\end{array}$ & \begin{tabular}{r|}
100.26 \\
100.35 \\
100.04 \\
100.36 \\
99.83
\end{tabular} & $\begin{array}{l}5.95 \\
5.97 \\
5.96 \\
6.00 \\
5.96\end{array}$ & $\begin{array}{l}4.03 \\
4.03 \\
4.04 \\
4.01 \\
4.05\end{array}$ & $\begin{array}{r}0.00 \\
.04\end{array}$ & $\begin{array}{l}4.11 \\
4.04 \\
4.02 \\
3.98 \\
3.93\end{array}$ & $\begin{array}{r}0.00 \\
.02 \\
-02\end{array}$ & $\begin{array}{l}4.05 \\
4.14 \\
3.99 \\
4.08 \\
4.06\end{array}$ & $\begin{array}{l}4.11 \\
4.04 \\
4.02 \\
4.02 \\
4.05\end{array}$ & \begin{tabular}{r}
-0.06 \\
+.10 \\
\hdashline .03 \\
+.06 \\
+.01
\end{tabular} & $\begin{array}{l}4.11 \\
\text { 4. } 04 \\
\text { 4. } 02 \\
\text { 4. } 00 \\
4.01\end{array}$ \\
\hline $\begin{array}{l}6 \\
7 \\
8 \\
9 \\
10\end{array}$ & $\begin{array}{l}46.72 \\
47.32 \\
47.17 \\
47.22 \\
47.80\end{array}$ & $\begin{array}{l}26.51 \\
26.30 \\
26.84 \\
27.21 \\
26.81\end{array}$ & $\begin{array}{r}.24 \\
.50 \\
.12 \\
\hdashline-.\end{array}$ & $\begin{array}{l}15.95 \\
15.95 \\
15.89 \\
15.86 \\
15.83\end{array}$ & $\begin{array}{c}.52 \\
.02 \\
.06 \\
\end{array}$ & $\begin{array}{r}19.08 \\
9.50 \\
9.58 \\
9.70 \\
9.69\end{array}$ & $\begin{array}{r}299.91 \\
99.57 \\
899.74 \\
100.05 \\
100.13\end{array}$ & $\begin{array}{l}5.97 \\
6.02 \\
6.00 \\
5.98 \\
6.04\end{array}$ & $\begin{array}{l}3.99 \\
3.94 \\
4.02 \\
4.06 \\
3.99\end{array}$ & $\begin{array}{r}2.05 \\
.07 \\
.02 \\
\hdashline \\
\hdashline\end{array}$ & $\begin{array}{l}3.95 \\
3.94 \\
3.92 \\
3.90 \\
3.88\end{array}$ & $\begin{array}{r}.08 \\
\hdashline-08 \\
\\
\hdashline\end{array}$ & $\begin{array}{l}3.79 \\
4.04 \\
4.06 \\
4.10 \\
4.08\end{array}$ & $\begin{array}{l}4.18 \\
4.15 \\
3.98 \\
3.90 \\
3.88\end{array}$ & $\begin{array}{l}-.40 \\
-.11 \\
+.08 \\
+.20 \\
+.20\end{array}$ & $\begin{array}{l}4.13 \\
4.08 \\
\text { 3. } 96 \\
\text { 3. } 90 \\
\text { 3. } 88\end{array}$ \\
\hline $\begin{array}{l}11 \\
13 \\
14 \\
15\end{array}$ & $\begin{array}{l}47.69 \\
46.91 \\
46.38 \\
47.33 \\
46.53\end{array}$ & $\begin{array}{l}27.14 \\
27.10 \\
27.36 \\
27.13 \\
26.63\end{array}$ & $\begin{array}{l}.63 \\
.83 \\
.10 \\
.44\end{array}$ & $\begin{array}{l}15.74 \\
15.65 \\
15.63 \\
15.63 \\
15.53\end{array}$ & $\begin{array}{r}.14 \\
.13 \\
.44\end{array}$ & $\begin{array}{r}9.56 \\
49.72 \\
9.28 \\
89.67 \\
9.62\end{array}$ & $\begin{array}{r}100.13 \\
100.15 \\
99.61 \\
99.86 \\
6100.65\end{array}$ & $\begin{array}{l}6.02 \\
5.95 \\
5.90 \\
6.00 \\
5.96\end{array}$ & $\begin{array}{l}4.03 \\
4.05 \\
4.10 \\
4.05 \\
.4 .02\end{array}$ & $\begin{array}{r}.08 \\
.11 \\
.01 \\
.08\end{array}$ & $\begin{array}{l}3.85 \\
3.85 \\
3.85 \\
3.84 \\
3.85\end{array}$ & $\begin{array}{r}.02 \\
.02 \\
.07\end{array}$ & $\begin{array}{l}\text { 4. } .02 \\
3.97 \\
3.94 \\
4.03 \\
4.12\end{array}$ & $\begin{array}{l}3.85 \\
4.11 \\
4.20 \\
3.87 \\
4.16\end{array}$ & $\begin{array}{l}+.17 \\
-.14 \\
-.26 \\
\pm .16 \\
-.04\end{array}$ & $\begin{array}{l}3.85 \\
4.03 \\
4.09 \\
3.86 \\
4.08\end{array}$ \\
\hline 18 & $\begin{array}{l}47.45 \\
47.34 \\
47.60 \\
47.15 \\
47.38\end{array}$ & $\begin{array}{l}27.40 \\
27.17 \\
27.40 \\
27.39 \\
27.63\end{array}$ & $\begin{array}{l}.07 \\
.48 \\
.13 \\
.30 \\
.54\end{array}$ & $\begin{array}{l}15.45 \\
15.42 \\
15.36 \\
15.27 \\
14.96\end{array}$ & $\begin{array}{l}.42 \\
.28 \\
.23 \\
.50 \\
.41\end{array}$ & $\begin{array}{l}9.16 \\
9.47 \\
9.47 \\
9.53 \\
9.58\end{array}$ & $\begin{array}{r}7100.20 \\
8100.17 \\
100.19 \\
100.14 \\
100.50\end{array}$ & $\begin{array}{l}\mathbf{5 . 9 8} \\
\mathbf{5 . 9 8} \\
\mathbf{6 . 0 0} \\
\mathbf{5 . 9 6} \\
\mathbf{5 . 9 6}\end{array}$ & $\begin{array}{l}\text { 4. } 07 \\
4.04 \\
4.06 \\
4.08 \\
4.10\end{array}$ & $\begin{array}{l}.01 \\
.06 \\
.02 \\
.04 \\
.07\end{array}$ & $\begin{array}{l}3.77 \\
3.77 \\
3.74 \\
3.74 \\
3.65\end{array}$ & $\begin{array}{l}.07 \\
.04 \\
.04 \\
.08 \\
.06\end{array}$ & $\begin{array}{l}3.86 \\
3.99 \\
3.98 \\
4.02 \\
4.02\end{array}$ & $\begin{array}{l}3.87 \\
3.99 \\
3.84 \\
3.94 \\
3.92\end{array}$ & $\begin{array}{r}-.01 \\
.00 \\
+.14 \\
+.08 \\
+.10\end{array}$ & $\begin{array}{l}3.86 \\
\text { 3. } 93 \\
3.82 \\
3.90 \\
3.85\end{array}$ \\
\hline 2123 & $\begin{array}{l}46.60 \\
47.33 \\
46.6 \\
47.29 \\
44.85\end{array}$ & $\begin{array}{l}27.21 \\
27.67 \\
27.2 \\
27.56 \\
27.94\end{array}$ & $\begin{array}{c}\text { Trace } \\
.22 \\
1.3 \\
.80 \\
2.00\end{array}$ & $\begin{array}{l}14.80 \\
14.74 \\
14.7 \\
14.63 \\
14.47\end{array}$ & $\begin{array}{r}.31 \\
<.50 \\
<.01 \\
.59 \\
.5\end{array}$ & $\begin{array}{c}10.24 \\
9.64 \\
9.6 \\
9.40 \\
1010.68\end{array}$ & $\begin{array}{c}999.94 \\
100.10 \\
99.4 \\
100.27 \\
11100.14\end{array}$ & $\begin{array}{l}5.98 \\
5.98 \\
5.94 \\
5.96 \\
5.78\end{array}$ & $\begin{array}{l}4.12 \\
4.12 \\
4.09 \\
4.09 \\
4.24\end{array}$ & $\begin{array}{r}.03 \\
.18 \\
.11 \\
.28\end{array}$ & $\begin{array}{l}3.68 \\
3.60 \\
3.63 \\
3.57 \\
3.62\end{array}$ & $\begin{array}{c}.05 \\
.08 \\
.10\end{array}$ & $\begin{array}{l}4.38 \\
4.06 \\
4.04 \\
3.95 \\
4.37\end{array}$ & $\begin{array}{l}3.73 \\
3.77 \\
4.17 \\
4.00 \\
4.46\end{array}$ & $\begin{array}{l}+.65 \\
+.29 \\
-.13 \\
-.05 \\
-.09\end{array}$ & $\begin{array}{l}\text { 3. } 73 \\
\text { 3. } 74 \\
3.99 \\
3.89 \\
\text { 4. } 18\end{array}$ \\
\hline 26 & $\begin{array}{l}47.22 \\
46.42\end{array}$ & $\begin{array}{l}26.94 \\
27.27\end{array}$ & $\begin{array}{l}1.05 \\
1.04\end{array}$ & $\begin{array}{l}14.45 \\
14.43\end{array}$ & $\begin{array}{r}1.27 \\
.47\end{array}$ & $\begin{array}{l}9.28 \\
9.64\end{array}$ & $\begin{array}{r}100.21 \\
1299.86\end{array}$ & $\begin{array}{l}5.98 \\
5.94\end{array}$ & $\begin{array}{l}4.02 \\
4.11\end{array}$ & $\begin{array}{l}.14 \\
.14\end{array}$ & $\begin{array}{l}3.54 \\
3.57\end{array}$ & $\begin{array}{l}.20 \\
.08\end{array}$ & $\begin{array}{l}3.92 \\
4.11\end{array}$ & $\begin{array}{l}4.16 \\
4.07\end{array}$ & $\begin{array}{l}-.24 \\
+.04\end{array}$ & $\begin{array}{l}4.02 \\
3.93\end{array}$ \\
\hline $\begin{array}{l}1 \text { Includes } 0.20 \mathrm{H}_{2} \mathrm{O}- \\
2 \text { Includes } 0.20 \mathrm{Fe}_{2} \mathrm{O}_{3}, 0 \\
3 \text { Includes } 0.07 \mathrm{Fe}_{2} \mathrm{O}_{3} \text { a } \\
1 \text { Includes } 0.34 \mathrm{H}_{2} \mathrm{O}-\text { - } \\
\text { 5 Includes } 0.13 \mathrm{H}_{2} \mathrm{O}-\text {. } \\
8 \text { Includes } 1.34 \mathrm{Fe}_{2} \mathrm{O}_{2} \text { aI }\end{array}$ & 0.12 & $(0$ & $\mathrm{mi}$ & 10). & & & & $\begin{array}{l}7 \text { In } \\
8 \mathrm{In} \\
9 \mathrm{In} \\
10 \mathrm{In} \\
11 \mathrm{In} \\
12 \mathrm{In}\end{array}$ & 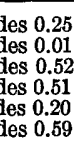 & $\begin{array}{l}\mathrm{H}_{2} \mathrm{O}- \\
\mathrm{Fe}_{2} \mathrm{O}_{3}- \\
\mathrm{Fe}_{2} \mathrm{O}_{3}\end{array}$ & 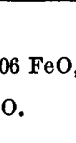 & & 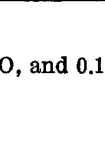 & $\mathrm{TiO}_{2}$ & & \\
\hline
\end{tabular}

LOCALITY AND REFERENCE FOR ANALYSIS IN TABLE 1

1. Viagrande, Etna, Italy, Di Franco, S., 1929, Reale Accad. Lincei, Atti Cl. Sci. fis. mat. nat. Rend., ser. 6, v. 9, p. 660 .

. Corporation quarry, Mount Royal, Canada, Harrington, B. J., 1905. Royal Soc. Canada Trans., v. 11, p. 25.

, Udiut, Hans, 1928, Arkiv Kemi, Mineralogi och Geologi, r. 9, p. 2. Naturw. K1., Sitzungsber. Abt. 1, v. 126, p. 544. 5. Bohemia, Niggli, Paul 1923, Zeitschr. Kristallographie, v. 57, p. 656 analysis 9 6. Kola peninsula, U.S.S.R., Kuz'menko, M. V., 1950, Akad. Nauk SSSR Doklady

Mori, Mount Baldo, Venetia, Italy, Cavinato, Antonio, 1927, Reale Accad. Lincei, Cl. Sci. fis. mat. nat. Mem. Ser. 6, v. 2, p. 325.

8. Ice Valley Region, British Columbia, Canada, Phillips, A. H., 1916, Am. Jour. Sci., 4th ser., $\nabla .42$, p. 473 .

9. Kinbane (White Head), County Antrim, Ireland, Niggli, Paul, 1923, Zeitschr. Kristallographie, v. 57, p. 656, analysis 10 .

10. Brevik, Norway, Tschermak, Gustav, 1917, Akad. Wiss. Wien Math.-Naturw. Kl., Sitzungsber. Abt. 1, v. 126, p. 544.

11. San Benito, Calif., Louderback, G. D., 1909, California Univ. Dept. Geol. Bull. 5 , p. 331, analysis 23 .

12. Pokolbin, New South Wales, Australia, Anderson, C., 1904, Australian Mus. Recs., v. 5, p. 129.

13. Ben Lomond, New South Wales, Australia, Anderson, C., 1906, Australian Mus. Recs., v. 6, p. 420. 14. Wykertown, N.J., Milton, Charles, and Davidson, Norman, 1950, Am. Min-
eralogist, v. 35, p. 502 .
15. Thetford mine, eastern Quebec, Canada, Poitevin, Eugene, 1938, Toronto Univ. Studies, Geol. Ser., no. 41, p. 58

16. Valley of Chivruai River, Lovozero massif, U.S.S.R. Vlasov, K. A., Kuz'menko, M. V., Es'kova, E. M., 1959, A kad. Nauk SSSR Inst. Mineralog. Geokhim, i Kristallokhim Redkika Elementov, p. 282, Analysis 3.

17. Amethyst Cove, Nova Scotia, Walker, T. L., and Parsons, A. L., 1922, Toronto Univ. Studies, Geol. ser., no. 14, p. 64 .

18. Puy de Marmant, Puy-dè-Dôme, France, Hey, M. H., 1932, Mineralog. Mag. v. 23, p. 246, analysis 1 .

19. Cape Blomidon, King's County, Nova Scotia, Hey, M. H., 1932, Mineralog. Mag. $\nabla .23$, p. 246 , analysis 5 .

20. Salesel, Leitmeritz, Bohemia, Hey, M. H., 1932, Mineralog. Mag. v. 23, p. 246,

21. Vrahozily (=Frauschile), nr. Boreslau., S.E. of 'Teplits-Schonau, Bohemia, Nováček, Radim, 1936. Praha, Národní Mus. Casopis, v. 110, p. 50.

Rhiw, Carnarvonshire, Scotland, Hey, M. H., 1932, Mineralog. Mag. v. 23, p. 246 , analysis 4.

23. Red Island, Hawkes Bay, North Island, New Zealand, Mason, Brian, 1955 New Zealand Jour. Sci. and Technology, sec. B, v. 36, p. 558 .

24. De Beers diamond mine, Kimberley, South Africa, Hey, M. H., 1932, Mineralog

Mag., v 23, p. 246, no. 6.
25. Highwood Mountains, Mont., Larsen, E. S., Hurlbut, C. S., Jr., Griggs, David Buie, B. F., and Burgess, C. H., 1941, Geol. Soc. America Bull., v. 52, p. 1852 26. Snake Hill, North Bergen, N. J., Hey, M. H., 1932, Mineralog. Mag. v. 23, p. 246 , no. 8 .

27. Budnany, S. W. of Praha, Bohemia, Kratochví, Frantisek, 1933, Praha Národ ntho Mus. Casopis, v. 107, p. 42. 
$0.10 \mathrm{Ca}$ atomic ratio), and only one reported as much as 2.00 percent $\mathrm{CaO}(0.28 \mathrm{Ca}$ atomic ratio). Several of the higher $\mathrm{CaO}$ values were reported in analyses significantly deficient in $\mathrm{Na}_{2} \mathrm{O}$, and thus raised the cationic content. However, little or no $\mathrm{CaO}$ was reported in several analyses that were significantly deficient in $\mathrm{Na}_{2} \mathrm{O}\left(+\mathrm{K}_{2} \mathrm{O}\right)$.

The $\mathrm{Si}$ and $\mathrm{Al}$ atomic ratios are generally $6.00 \pm 0.10$ and $4.00 \pm 0.10$, respectively. Only one analysis, No. 25 , yields a $\mathrm{Si}$ atomic ratio with a greater deviation, -0.22. Deviations in $\mathrm{Al}$ content greater than 0.10 are slightly more common, being found in four analyses. The greatest deviation, +0.24 is in analysis No. 25 .

The atomic ratios for $\mathrm{Si}, \mathrm{Al}, \mathrm{Na}$, and $\mathrm{Ca}$ in No. 25 indicate a slight $\mathrm{CaAl}$ replacement of $\mathrm{NaSi}$. This type of replacement is also indicated in No. 13. Ca replacement of $\mathrm{Na}_{2}\left(+\mathrm{K}_{2}\right)$ is indicated in No. 23, and No. 26. A little of both types may be suggested by the atomic ratios of Nos. 12 and 27. In most of the analyses, however, the atomic ratios for $\mathrm{Ca}$ are so low, and the $\mathrm{Si}$ and $\mathrm{Al}$ ratios are so close to the theoretical values that the low $\mathrm{Na}$ ratios cannot be explained by either type of replacement.

The $\mathrm{H}_{2} \mathrm{O}$ content of these natrolites is very constant and very close $( \pm 0.15)$ to the theoretical 4.00 in 24 of the 27 analyses, even though $(\mathrm{Na}+\mathrm{K})$ is more than 0.20 deficient in one-third of the analyses. For some of the analyses that are low in $\mathrm{Na}$ but for which the atomic ratio of $\mathrm{H}_{2} \mathrm{O}$ is near 4.00 or even higher, the $\mathrm{H}_{2} \mathrm{O}$ value can be accounted for if the $\mathrm{Ca}$ present is considered as contributing to the $\mathrm{H}_{2} \mathrm{O}$ content in the $3: 1$ ratio as in scolecite. In No. 27 , for example, the atomic ratio for $(\mathrm{Na}+\mathrm{K})$ is only 3.65 , and consequently, accounts for a $\mathrm{H}_{2} \mathrm{O}$ molecular ratio of only $3.65 \mathrm{H}_{2} \mathrm{O}$. However, the atomic ratio of $\mathrm{Ca}, 0.14$, tripled (0.42) and added to 3.65 gives a calculated $\mathrm{H}_{2} \mathrm{O}$ ratio of 4.07 , compared to the determined value of 4.11. Other analyses in which the atomic ratio for $(\mathrm{Na}+\mathrm{K})$ is much lower than the $\mathrm{H}_{2} \mathrm{O}$ molecular ratio and for which it is necessary to include the $\mathrm{Ca}$ value tripled to obtain a calculated $\mathrm{H}_{2} \mathrm{O}$ value comparable to the determined value are Nos. 17, 20, 24, and 25 . This suggests that $\mathrm{Ca}$ is an intrinsic constituent of these natrolites. In other analyses, as in No. 26, inclusion of the Ca tripled in the calculated water computation yields a $\mathrm{H}_{2} \mathrm{O}$ value that is somewhat higher than the determined value, suggesting that some, at least, of the $\mathrm{Ca}$ may be extraneous to the natrolite molecule. In other analyses, as in No. 21, the determined water is considerably higher than the calculated. This analysis reports no Ca. Such a high $\mathrm{H}_{2} \mathrm{O}$ content may be due to adsorption of $\mathrm{H}_{2} \mathrm{O}$ in a humid atmosphere by the finely ground sample before analysis, $\mathrm{H}_{2} \mathrm{O}$ - being seldom reported in analyses of zeolites, or a high $\mathrm{H}_{2} \mathrm{O}$ content may be due to the presence of hydronium ions, which would compensate for the low $\mathrm{Na}$ content.

\section{SCOLECITE \\ $\mathrm{Ca}_{2.0} \mathrm{Al}_{4.0} \mathrm{Si}_{6.0} \mathrm{O}_{20} \cdot 6.0 \mathrm{H}_{2} \mathrm{O}$}

The 16 analyses used to study the composition and water content of scolecite are given in table 2 , together with their atomic ratios calculated on the basis of 20 oxygen atoms. The $\mathrm{CaO}$ content of these analyses is quite constant, ranging only between 13.58 and 14.86 percent. The corresponding atomic ratio for $\mathrm{Ca}$ ranges only between 1.89 and 2.09 , or $2.0 \pm 0.11 . \mathrm{MgO}$ is reported in only four of the analyses. The highest amount is only 0.32 percent or an atomic ratio for $\mathrm{Mg}$ of only 0.06. $\mathrm{Na}_{2} \mathrm{O}$ was reported in one-half of the analyses, most of which also reported $\mathrm{K}_{2} \mathrm{O}$. However, the amounts found were low, and the highest atomic ratio for $(\mathrm{Na}+\mathrm{K})$ in any of the analyses was only 0.20 .

For most of the analyses the atomic ratios for $\mathrm{Si}$ and Al were within 0.10 of the theoretical 6.00 and 4.00 , respectively. As these values and those for $\mathrm{Ca}$ are so close to the theoretical, there is little indication of replacement except in analyses 14,15 , and 16, in which the atomic ratios for $\mathrm{Ca}$ are the lowest and those for $(\mathrm{Na}+\mathrm{K})$ the highest. In No. 15 the atomic ratio for $(\mathrm{Na}+\mathrm{K}), 0.20$, and the deficiency in the atomic ratios for $\mathrm{Ca}, 0.08$, suggest slight replacement of $\mathrm{Ca}$ by $(\mathrm{Na}+\mathrm{K})_{2}$. The deviation in the atomic values of No. 15 for $\mathrm{Si}$ and $\mathrm{Al}$ of -0.12 and +0.14 , respectively, would suggest $\mathrm{CaAl}$ replacement for $\mathrm{NaSi}$ if the $\mathrm{Ca}$ were not already lower and the $\mathrm{Na}$ higher than the theoretical values. In Nos. 14 and 16 replacement is of the $\mathrm{Na}_{2} \rightarrow \mathrm{Ca}$ type.

The molecular ratios for $\mathrm{H}_{2} \mathrm{O}$ for all the analyses are within 0.20 of the theoretical value except for No. 2, for which $\mathrm{H}_{2} \mathrm{O}$ is low, 5.71, and No. 6, for which $\mathrm{H}_{2} \mathrm{O}$ is high, 6.32. However, the high $\mathrm{H}_{2} \mathrm{O}$ molecular value in No. 6 can be partially accounted for if $\mathrm{H}_{2} \mathrm{O}$ equivalent to $\mathrm{Na}$ is added to the tripled $\mathrm{Ca}$ value. Molecular values of $\mathrm{H}_{2} \mathrm{O}$, calculated on the basis of a $1: 3$ relation between $\mathrm{Ca}$ atoms and $\mathrm{H}_{2} \mathrm{O}$ molecules and $1: 1$ relation between $\mathrm{Na}$ atoms and $\mathrm{H}_{2} \mathrm{O}$ molecules, agree fairly well with the determined $\mathrm{H}_{2} \mathrm{O}$ molecular ratios. For analyses 15 and 16 , as well as for No. 6 , it is necessary to include $\mathrm{H}_{2} \mathrm{O}$ equivalent to the $(\mathrm{Na}+\mathrm{K})$ present to produce a calculated $\mathrm{H}_{2} \mathrm{O}$ value more nearly approximating the determined $\mathrm{H}_{2} \mathrm{O}$ value.

$$
\begin{gathered}
\text { MESOLITE } \\
\mathrm{Na}_{1.33} \mathrm{Ca}_{1.33} \mathrm{Al}_{4.0} \mathrm{Si}_{6.0} \mathrm{O}_{20} \cdot 5.33 \mathrm{H}_{2} \mathrm{O}
\end{gathered}
$$

Analyses of 17 mesolites, together with their atomic ratios calculated on the basis of 20 oxygen atoms, are given in table 3. For 13 of the 17 analyses, Nos. 4-16, the atomic ratio for $\mathrm{Ca}$ is close to the theoretical value 
TABLE 2.-Analyses of scolecite and their calculated atomic ratios

[In order of decreasing $\mathrm{CaO}$ content]

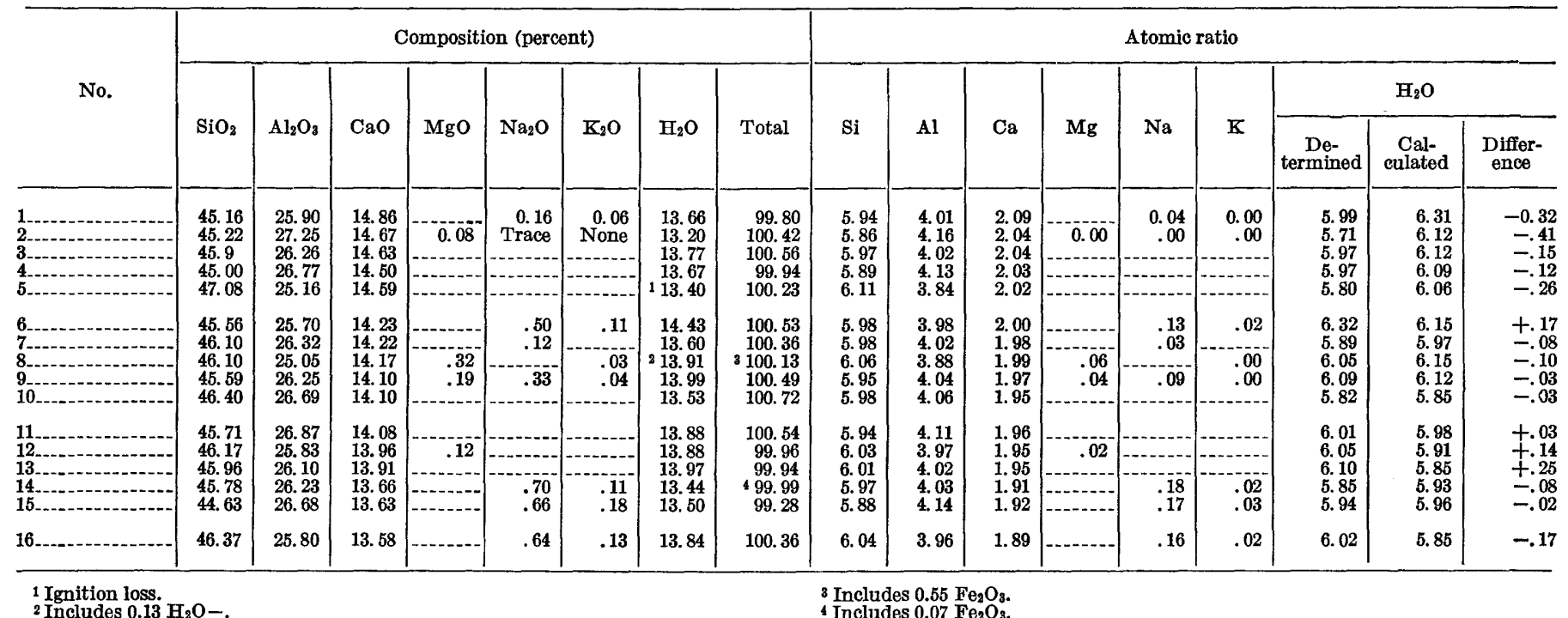

LOCALITY AND REFERENCE FOR ANALYSES IN TABLE 2

1. Syhadree Mountains, Bombay, India, Hey, M. H., 1936, Mineralog. Mag. v. 24,

2. Nr. Azhar, Caucasus, USSR, Shkabara, M. N., 1948, Akad. Nauk SSSR Doklady, v. 63 , p. 730

3. Teigarhorn, Berufjord, Iceland, Cavinato, Antonio., 1927, Reale Accad. Lincei, Ci. Sci. fis. mat. nat. Mem. ser. 6, v. 2, p. 331 .

4. Maderanerthal, Switzerland, Cavinato, Antonio., 1927, Reale Accad. Lincei. Cl. Sci. fis. mat. nat. Mem. ser. 6, v. 2, p. 33

5. Teigarhorn, Iceland, Koizume, Mitsue, 1953, Mineralog. Jour. Japan, v. 1, p. 39 6. Valle di Viù, Valle di Lanzo, Italy, Gennaro, Virginia, 1929, Reale Accad. Sci. Torino Atti, v. 64, p. 141.

7. Poonah, India, Tschermak, Gustav, 1917, Akad. Wiss. Wien Math-naturw. Kl. Sitzungsber. Abt. I, v. 126, p. 544 . 8. An Gearna, Mull, Scotland, M'Lintock, W. F. P., 1915, Royal Soc. Edinburgh
Trans, v. 51, p. 5.

of 1.33 , being $1.33 \pm 0.07$. In the other four, $\mathrm{Ca}$ is about 0.20 higher than theoretical value in three, (Nos. 1, 2, and 3), and 0.12 lower in one, (No. 17). In the three analyses in which $\mathrm{Ca}$ is high, $\mathrm{Na}$ is low; in $\mathrm{No} .17$, in which $\mathrm{Ca}$ is low, $\mathrm{Na}$ is high. In this last analysis the relation between $\mathrm{Ca}$ and $\mathrm{Na}$ can be interpreted as replacement of $0.12 \mathrm{Ca}$ by $0.22 \mathrm{Na}$, but the relations between $\mathrm{Ca}$ and $\mathrm{Na}$ and between $\mathrm{Si}$ and $\mathrm{Al}$ in Nos. 1, 2, and 3, do not permit such an interpretation. In the group of 13 in which $\mathrm{Ca}$ is very constant and close to the theoretical value, the amount of $\mathrm{Na}$ present varies considerably, and in most is deficient. However, because of the fact that several contain a little $K$, or that $\mathrm{Ca}$ is slightly greater than the theoretical 1.33, the cationic charge is $4.00 \pm 0.10$ for more than half of these analyses. In the analyses for which the positive charge is less than 3.90, slight adjustments in the amounts of $\mathrm{Si}$ and $\mathrm{Al}$ present produce the lower negative charges that just balance the lower positive charges.

The $\mathrm{Si}$ ratio is $6.00 \pm 0.10$ for all the analyses given in table 3 , and the $\mathrm{Al}$ ratio is $4.00 \pm 0.10$ for all but two, Nos. 10 and 14, in which it is 4.11 and 4.16, respectively. However, as the respective $\mathrm{Si}$ ratios for these analyses are not low by similar amounts, replacement of the $\mathrm{CaAl} \longrightarrow \mathrm{NaSi}$ type is not indicated. Nor is similar
9. Alomatà, Eritrea, Italy, Scherillo, Antonio, 1938, Periodico Mineralogia, Rom a,

v. 9, p. 68. The Mineralogist, Portland, Oreg., v. 10, p. 108.

11. Teigarhorn, Iceland, Koizumi, Mitsue, 1953, Mineralog. Jour. Japan, v. 1, p. 39. 12. Teigarhorn, Iceland, Bauer, Jaroslav, and Malkova, Ludmila, 1959, Sci. Papers

Inst. Chem. Technology, Prague, p. 72. Antonio, 1927, Reale Accad. Lincei,
13. Miage, Monte Bianco, Italy, Cavinato, Antol Cl. Sci. fis. mat. nat. Mem., ser. 6, v. 2, p. 331 .

14. Digby Gut, Annapolis County, Nova Scotia, Walker, T. L., and Parsons, A. L. 1922, Toronto Univ. Studies, Geol. Ser. no. 14, p. 68

15. Valle di Viù, Valle di Lanzo, Italy, Gennaro, Virginia, 1929, Reale Accad. Sci. Torino Atti, v. 64, p. 141.

16. Bettolina Pass, Valle di Ayas, Monte Rosa, Italy, Gennaro, Virginia, 1929, Reale Accad. Sci. Torino Atti, v. 64, p. 137.

replacement, or the reverse, except in a very slight degree, perhaps, indicated in any of the other analyses because of the close agreement of the $\mathrm{Si}$ and $\mathrm{Al}$ ratios with the theoretical value.

For most of the analyses the determined $\mathrm{H}_{2} \mathrm{O}$ values yield molecular ratios that agree fairly woll with the the theoretical values. Furthermore, molecular $\mathrm{H}_{2} \mathrm{O}$ ratios calculated on the basis of a 1:1 relation between $\mathrm{Na}(+\mathrm{K})$ ions and $\mathrm{H}_{2} \mathrm{O}$ molecules, and a $1: 3$ relation between $\mathrm{Ca}$ ions and $\mathrm{H}_{2} \mathrm{O}$ molecules, agree within 0.20 molecule with the $\mathrm{H}_{2} \mathrm{O}$ ratios based on the determined $\mathrm{H}_{2} \mathrm{O}$, except for analyses Nos. 9, 14, and 16. For Nos. 9 and 14, the determined $\mathrm{H}_{2} \mathrm{O}$ ratios are very high, 5.77 and 5.85, respectively. For No. 16 the determined $\mathrm{H}_{2} \mathrm{O}$ ratio is only 5.42 , quite close to the theoretical 5.33, but it is much higher than the calculated $\mathrm{H}_{2} \mathrm{O}$ because of the low $\mathrm{Ca}$ and $\mathrm{Na}$ content of this sample. $\mathrm{Na}$ is also low in Nos. 9 and 14. The high $\mathrm{H}_{2} \mathrm{O}$ content reported for these analyses may be due to hydronium ion, whose presence would compensate for their low $\mathrm{Na}$ content. On the other hand, these high $\mathrm{H}_{2} \mathrm{O}$ values may be due to adsorption of $\mathrm{H}_{2} \mathrm{O}$ before analysis by the finely ground specimen in a humid environment. In most of these analyses only total water was reported: $\mathrm{H}_{2} \mathrm{O}$ - and $\mathrm{H}_{2} \mathrm{O}+$ were differentiated only in analysis 
$\mathrm{T}_{\mathrm{ABLE}}$ 3.-Analyses of mesolite, and their calculated atomic ratios

[In order of decreasing $\mathrm{CaO}$ content]

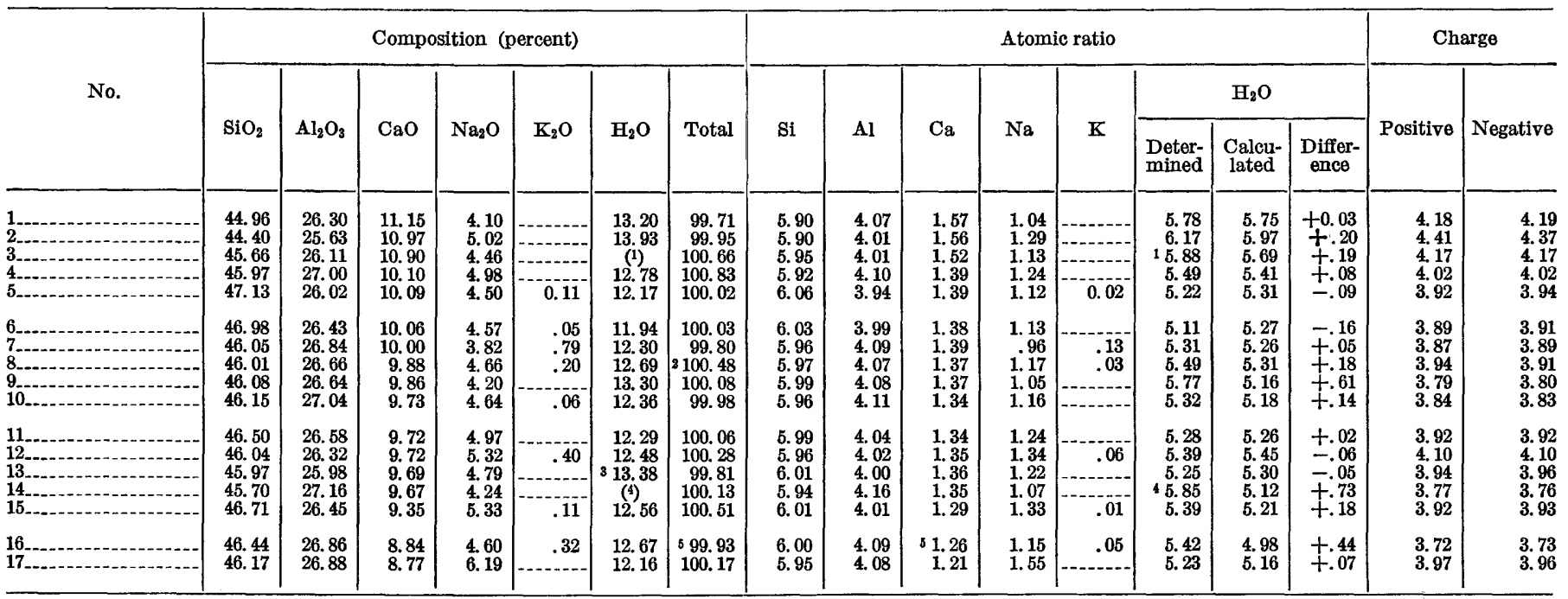

1 Ignition loss, 13.53 .

2 Includes $0.38 \mathrm{Fe}_{2} \mathrm{O}_{3}\left(\mathrm{Fe}^{3+}\right.$ atomic ratio $=0.04$ )

Ignition loss, 13.36 .

: Includes $0.20 \mathrm{MgO}(\mathrm{Mg}$ atomic ratio $=0.04)$.

LOCALITY AND REFERENCES FOR ANALYSES IN TABLE 3

1. Berufjord, Iceland, Cavinato, Antonio, 1927, Reale. Accad. LinceiYCl. Sci. fis. mat. nat. Mem., Roma, ser. 6, v. 2, p. 339

Kalageran, S. of Tiflis, USSR., Tvalchrelidze, A. A., 1922, Univ. Tiflis Bull. no. 2 , p. 15. Mean of 4 analyses.

Kilpatrick, Dumbartonshire, Scotland, Koizumi, Mitsue, 1953, Mineralog.

Jour. Japan. . 1, p. 39 .
Nishishioda-mura, Nagano Pref., Japan, Koizume, Mitsue, 1953, Mineralog. Jour. Japan, $\nabla .1$, p. 39, no. 15 .

5. Iceland, Hey, M. H., 1933, Mineralog. Mag. v. 23, p. 423, no. 2

Syhadree Mountains, Bombay, India, Hey, M. H., 1933, Mineralog. Mag., $\nabla$. 23, p. 423, no. 3 .

. Mag $\forall .23$, Syhadree Mountains, Bombay, India, Hey, M.H., 1933, Mineralog.

8. Cape d, , 23, p. 423, no. 1.

Univ. Studies, Geol. Ser., no. 14, p. 58 , no. 1 .

13. If the value for total water had been used to calculate the determined $\mathrm{H}_{2} \mathrm{O}$ molecular ratio for No. 13 , the $\mathrm{H}_{2} \mathrm{O}$ ratio would have been 5.84 , instead of 5.25 , the value abtained when the $\mathrm{H}_{2} \mathrm{O}+$ value was used in the calculation. Thus $\mathrm{H}_{2} \mathrm{O}$ ratios based on total $\mathrm{H}_{2} \mathrm{O}$ values may be high because of adsorbed water.

TABLE 4.-Analyses of high- $\mathrm{Na}$ mesolites

PERCENT

\begin{tabular}{|c|c|c|c|c|c|c|c|}
\hline & $\mathrm{SiO}_{2}$ & $\mathrm{Al}_{2} \mathrm{O}_{3}$ & $\mathrm{CaO}$ & $\mathrm{NaO}$ & $\mathrm{K}_{2} \mathrm{O}$ & $\mathrm{H}_{2} \mathrm{O}$ & Total \\
\hline $\begin{array}{l}1 \\
2 \\
3\end{array}$ & $\begin{array}{l}40.03 \\
41.15 \\
40.59\end{array}$ & $\begin{array}{l}27.88 \\
29.49 \\
29.69\end{array}$ & $\begin{array}{l}6.03 \\
5.33 \\
5.06\end{array}$ & $\begin{array}{l}10.05 \\
11.02 \\
11.00\end{array}$ & $\begin{array}{r}0.40 \\
.25 \\
.51\end{array}$ & $\begin{array}{r}111.10 \\
13.52 \\
13.58\end{array}$ & $\begin{array}{r}2100.29 \\
100.76 \\
100,43\end{array}$ \\
\hline
\end{tabular}

ATOMS PER TWELFTH CELL

\begin{tabular}{|c|c|c|c|c|c|}
\hline & $\mathrm{Si}$ & Al & $\mathrm{Ca}(+\mathrm{Mg})$ & $\mathrm{Na}(+\mathrm{K})$ & $\mathrm{H}_{2} \mathrm{O}$ \\
\hline $\begin{array}{l}1 \\
2 \\
3\end{array}$ & $\begin{array}{l}5.48 \\
5.45 \\
5.41\end{array}$ & $\begin{array}{l}4.50 \\
4.60 \\
4.66\end{array}$ & $\begin{array}{r}0.92 \\
.76 \\
.72\end{array}$ & $\begin{array}{l}2.73 \\
2.86 \\
2.92\end{array}$ & $\begin{array}{l}5.07 \\
5.97 \\
6.03\end{array}$ \\
\hline
\end{tabular}

1 Includes $3.12 \mathrm{H}_{2} \mathrm{O}-$

2 Includes $0.85 \mathrm{~F}_{32} \mathrm{O}_{3}, 0.59 \mathrm{FeO}, 0.22 \mathrm{MgO}$ (0.04 atomic ratio), and $0.02 \mathrm{TiO}_{2}$.

1. Rio Cambone, Montiferro, Sardinia, Deriu, M. 1954, Periodico Mineralogia Roma v. $23, \mathrm{p}_{\text {. }} 42$.

Nauk, Věstník Art. 2, p. 11
9. Berufjord, Iceland, Cavinato, Antonio, 1927, Reale Accad. Lincei C1. Sci. fis. mat. nat. Mem. Roma, ser. 6, v. 2, p. 339.

10. Kvivig, Strömö, Faroe Islands, Hey, M. H., 1933, Mineralog. Mag. v. 23, p. 423,

11. Faroe Islands, Görgey, R., 1909, Tschermaks Mineralog. Petrog. Mitt. v. 28, p. 95. 12. Nova Scotia, Walker, T. L., and Parsons, A. L., 1922, Toronto Univ. Studies, Geol. Ser., no. 14, p. 58, no. II

13. Osterö, Faroe Islands, Clarke, F. W., 1910, U.S. Geol. Survey Bull 419, p. 285, B. 14. Nishishioda-mura, Nagano Pref., Japan, Koizumi, Mitsue, 1953, Mineralog. Jour. Japan, v. 1, p. 39, no. 14.

15. Poonah, Bombay, India, Bowman, H. L., 1909, Mineralog. Mag. v. 15, p. 220. 16. Yastreb, near Kurdjali, Bulgaria, Kostov, Ivan, 1958, Sofia UỦ niv., Biolog.-

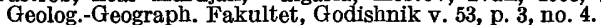

17. North Table Mountain, Golden, Colo., Clarke, F. W., 1910, U.S. Geol. Survey Bull. 419 , p. $285, A$.

Three analyses of high $\mathrm{Na}$ mesolite are shown in table 4. These analyses are very similar to each other but very different from the mesolite analyses given in table 3 , being respectivley lower in $\mathrm{Si}$ and $\mathrm{Ca}$, and higher in $\mathrm{Al}$ and $\mathrm{Na}$. Such compositions as indicated by these analyses cannot be derived from theoretical mesolite by either $\mathrm{NaSi} \rightleftarrows \mathrm{CaAl}$ or $\mathrm{Na}_{2} \rightleftarrows \mathrm{Ca}$ replacement. They can only be derived from mesolite by replacement of an average of about $0.55 \mathrm{CaSi}$ by $0.55 \mathrm{Na}_{3} \mathrm{Si}$. These analyses are very similar to some of the analyses of gonnardite published by Meixner, Hey, and Moss (1956) and by Kostov (1958), and to some high-Na thomsonites published or cited by Hey (1932). Such compositions can be derived from thomsonite by a combination of $\mathrm{Na}_{2} \longrightarrow \mathrm{Ca}$ and $\mathrm{NaSi} \longrightarrow \mathrm{CaAl}$ replacement.

\section{DISCUSSION}

The most significant finding resulting from this study of analyses of the natrolite group of zeolites is that the amounts of $\mathrm{Si}, \mathrm{Al}$, and $\mathrm{Ca}$ present usually agree very well with the amounts required by the formulas but that the amount of $\mathrm{Na}$ present is often deficient. As a consequence, scolecites are the most uniform in com- 


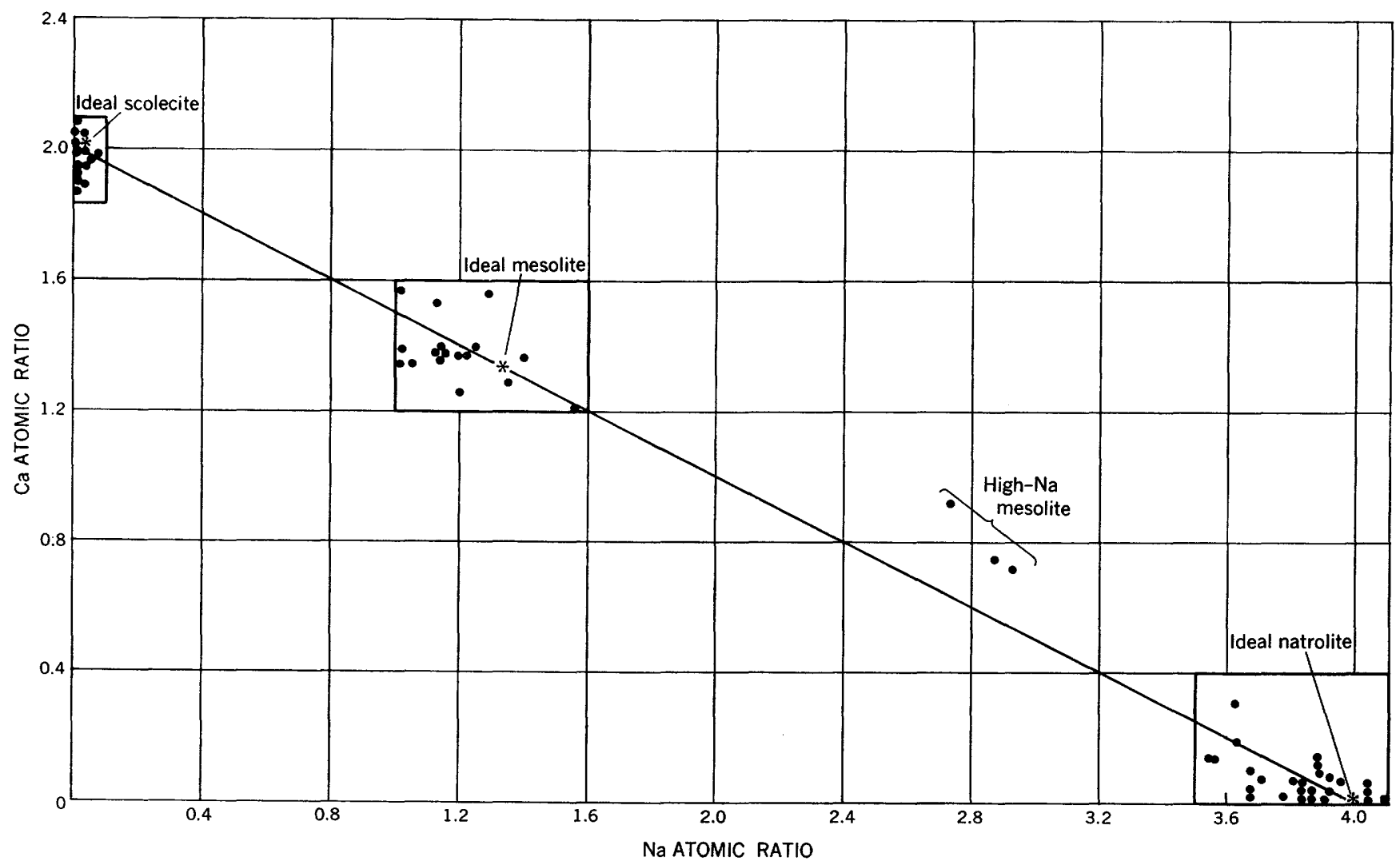

FIGURe 1.-Relation between $\mathrm{Ca}(+\mathrm{Mg})$ and $\mathrm{Na}(+\mathrm{K})$ in natrolites, scolecites, and mesolites.

position and conform most closely with the requirements of the formula, and natrolites deviate most from the requirements of the formula. In mesolites the $\mathrm{Ca}$ is usually close to the theoretical value, but the $\mathrm{Na}$ is often significantly lower than the theoretical value. As the other constituents deviate so little from the theoretical, the deficiency in $\mathrm{Na}$ cannot be interpreted, generally, in terms of either type of replacement, $\mathrm{Ca} \longrightarrow \mathrm{Na}_{2}$ or $\mathrm{CaAl} \longrightarrow \mathrm{NaSi}$. In some natrolites there is sufficient $\mathrm{Ca}$ or $\mathrm{K}$ present to produce a positive cationic charge close to the theoretical 4.00. In some mesolites also the $\mathrm{Ca}$, although close to the theoretical, is enough higher to bring the positive charge close to 4.00. However, in other natrolites and mesolites the positive cationic charge is only 3.75 , or even less. Slight adjustments in the amounts of $\mathrm{Si}$ and $\mathrm{Al}$ present produce the lower negative charges that just balance the lower positive charges.

The relation between $\mathrm{Ca}$ and $\mathrm{Na}$ in these zeolites is shown graphically in figure 1 . The points representing the relation between $\mathrm{Ca}$ and $\mathrm{Na}$ in scolecites all fall in a very small area closely grouped around the point representing ideal scolecite, whereas the points representing the relation between $\mathrm{Ca}$ and $\mathrm{Na}$ in mesolites and natrolites are more scattered. Most of the points representing the relation between $\mathrm{Ca}$ and $\mathrm{Na}$ in analyses of mesolites and natrolites fall left of the points representing ideal mesolite and ideal natrolite, respectively, thus indicating lower $\mathrm{Na}$ than ideally presumed to be present. However, three points representing the relation between $\mathrm{Ca}$ and $\mathrm{Na}$ in samples of high $\mathrm{Na}$ mesolite fall lower and far to the right of the mesolite area; closer to the natrolite area than to the mesolite area. In composition these analyses resemble gonnardites or high-Na thomsonites rather than mesolites.

Most $\mathrm{H}_{2} \mathrm{O}$ molecular ratios based on reported $\mathrm{H}_{2} \mathrm{O}$ contents are close to the theoretical value specified in the formula. Also, most of the $\mathrm{H}_{2} \mathrm{O}$ values calculated from the $\mathrm{Ca}(+\mathrm{Mg})$ and $\mathrm{Na}(+\mathrm{K})$ present agree within 0.20 molecule of the $\mathrm{H}_{2} \mathrm{O}$ values based on the amount of $\mathrm{H}_{2} \mathrm{O}$ reported in the analysis. In general the determined $\mathrm{H}_{2} \mathrm{O}$ ratios are higher than the calculated ratios. A few determined $\mathrm{H}_{2} \mathrm{O}$ values are very high. As most zeolite analyses report only total $\mathrm{H}_{2} \mathrm{O}$, and do not differentiate $\mathrm{H}_{2} \mathrm{O}$ - and $\mathrm{H}_{2} \mathrm{O}+$, these higher values for determined $\mathrm{H}_{2} \mathrm{O}$ may be due to adsorbed $\mathrm{H}_{2} \mathrm{O}$, which is probably very slight in most of the samples analyzed but in some may be considerable, and so produce an unrealistically high $\mathrm{H}_{2} \mathrm{O}$ content particularly if the finely powdered sample has been in a humid environment before analysis. The dehydration curves of Koizumi (1953) and Peng (1955) indicate that $\mathrm{H}_{2} \mathrm{O}$ 
that is an intrinsic part of the structure does not begin to come off below about $150^{\circ} \mathrm{C}$; consequently determination of $\mathrm{H}_{2} \mathrm{O}-$ at $110^{\circ} \mathrm{C}$ is perfectly feasible. It is therefore recommended that $\mathrm{H}_{2} \mathrm{O}-$ be routinely determined in the zeolites.

The highest $\mathrm{H}_{2} \mathrm{O}$ values in both the natrolites and the mesolites occur in analysis that are very low in $\mathrm{Na}$ and that have the lowest positive charges. It may be, therefore, that these high $\mathrm{H}_{2} \mathrm{O}$ values are caused by hydronium ions which compensate for the low cationic content of the zeolite.

\section{REFERENCES}

Hey, M. H., 1932, Studies on the zeolites. Part III. Natrolite and metanatrolite: Mineralog. Mag., v. 23, p. 243-289.

1933, Studies on the zeolites. Part V. Mesolite: Mineralog. Mag., v. 23, p. 421-447.
-1936, Studies on the zeolites. Part IX, Scolecite and metascolecite: Mineralog. Mag., v. 24, p. 227-253.

-1955, An index of mineral species and varieties arranged chemically, 2d ed.: London, British Museum (Natural History), 728 p.

Koizumi, Mitsue, 1953, Studies on water in minerals. Part I. The differential thermal analysis curves and the dehydration curves of zeolites: Mineralog. Jour. Japan, v. 1, p. 36-47.

Kostov, Ivan, 1958, Zeolites in Bulgaria: scolecite, mesolite, "gonnardite," and thomsonite: Sofia Univ. Biolog.Geolog.-Geograph. Fakultet, Godishnik, v. 53, p. 1-24.

Meier, W. M., 1960, The crystal structure of natrolite: Zeitschr. Kristallographie, v. 113, p. 430-444.

Meixner, Heinz, Hey, M. H., and Moss, A. A., 1956. Some new occurrences of gonnardite: Mineralog. Mag., v. 31, p. 265271.

Peng, C. J., 1955, Thermal analysis study of the natrolite group: Am. Mineralogist, v. 40, p. 834-856.

Taylor, W. H., Meek, C. A., and Jackson, W. W., 1933, The structures of the fibrous zeolites: Zeitschr. Kristallographie, v. 84, p. $373-398$. 



\section{Studies of the Zeolites}

Compositional

Relations among

Thomsonites

Gonnardites

\section{and Natrolites}

By MARGARET D. FOSTER

SHORTER CONTRIBUTIONS TO GENERAL GEOLOGY

GEOLOGICAL SURVEY PROFESSIONAL PAPER 504-E

Relations among thomsonites, high-sodium thomsonites, gonnardites, high-sodium mesolites, and natrolites as indicated by published analyses

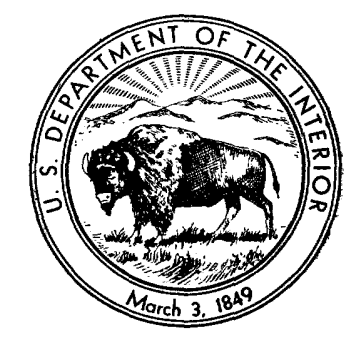





\title{
SHORTER CONTRIBUTIONS TO GENERAL GEOLOGY
}

\section{Studies of the Zeolites \\ COMPOSITIONAL RELATIONS AMONG THOMSONITES, GONNARDITES, AND NATROLITES}

\author{
By Margaret D. Foster
}

\begin{abstract}
A study of post-1885 analyses of thomsonite selected from Hey's 1932 compilation confirms the isomorphous series between thomsonite and faroelite. This isomorphous series, which is characterized by replacement of $\mathrm{CaAl}$ by $\mathrm{NaSi}$, was recognized by Winchell (1925, 1926) and Hey (1932). Hey's formula for gonnardite is related to thomsonite in the same way and carries this line of replacement a step beyond faroelite. However, the total number of cations, and the relation between $\mathrm{Si}$ and $\mathrm{Al}$ and $\mathrm{Ca}$ and $\mathrm{Na}$ in analyses of gonnardite, including those published by Meixner, Hey, and Moss (1956) indicate replacement of $\mathrm{Ca}$ by $\mathrm{Na}_{2}$ as well as replacement of $\mathrm{Ca}$ as $\mathrm{CaAl}$ by NaSi. Similar numbers of total cations, and similar relations between $\mathrm{Si}$ and $\mathrm{Al}$ and $\mathrm{Ca}$ and $\mathrm{Na}$ were also found in some analyses of high $\mathrm{Na}$ thomsonites and in high $\mathrm{Na}$ mesolites. Plotted points representing the relation between $\mathrm{Ca}$ and $\mathrm{Na}$ in these analyses fall, not along the thomsonite-faroelite line, but along a line representing dual replacement, to the same degree, of $\mathrm{Ca}$ by $\mathrm{Na}_{2}$ and of $\mathrm{CaAl}$ by NaSi. Such dual replacement of $\mathrm{Ca}$ in thomsonite leads theoretically to natrolite:
\end{abstract}

Thomsonite: $\mathrm{Ca}_{2.0} \mathrm{Na}_{1.0} \mathrm{Al}_{5.0} \mathrm{Si}_{5.0} \mathrm{O}_{20} \cdot 6.0 \mathrm{H}_{2} \mathrm{O}$

$$
\mathrm{Ca}_{1.0} \mathrm{Na}_{2.5} \mathrm{Al}_{4.5} \mathrm{Si}_{5.5} \mathrm{O}_{20} \cdot 5.0 \mathrm{H}_{2} \mathrm{O}
$$

Natrolite: $\mathrm{Ca}_{.0} \mathrm{Na}_{4.0} \mathrm{Al}_{4.0} \mathrm{Si}_{6.0} \mathrm{O}_{20} \cdot 4.0 \mathrm{H}_{2} \mathrm{O}$

The analyses alone suggest an isomorphous series between thomsonite and natrolite, with gonnardite as the intermediate member.

For such a series only formulas indicating ranges of composition are adequate. As there appears to be no natural hiatus in composition between thomsonite and gonnardite, the division was arbitrarily fixed at the point where $\mathrm{Ca}$ and $\mathrm{Na}$ are equal. The suggested range formulas for the series are:

Thomsonite: $\mathrm{Na}_{1.0-1.6} \mathrm{Ca}_{2.0-1.6} \mathrm{Al}_{5.0-4.8} \mathrm{Si}_{5.0-5.2} \mathrm{O}_{20} \cdot 6.0-5.6 \mathrm{H}_{2} \mathrm{O}$

Gonnardite: $\mathrm{Na}_{1.6-3.4} \mathrm{Ca}_{1.6-0.4} \mathrm{Al}_{4.8-4.2} \mathrm{Si}_{5.2-5.8} \mathrm{O}_{20} \cdot 5.6-4.4 \mathrm{H}_{2} \mathrm{O}$

Natrolite: $\mathrm{Na}_{3.4-4.0} \mathrm{Ca}_{0.4-0.0} \mathrm{Al}_{4.2-4.0} \mathrm{Si}_{5.8-6.0} \mathrm{O}_{20} \cdot 4.4-4.0 \mathrm{H}_{2} \mathrm{O}$

Although thomsonite and natrolite have similar aluminosilicate frameworks, they differ considerably in detail. Thus there may be a structural hiatus between thomsonite and natrolite like that between muscovite and lepidolite. No study has been made of the structure of gonnardite. The indices of refraction of gonnardite are intermediate between those of thomsonite and natrolite, those of thomsonite the higher, and those of natrolite the lower. However, the optic sign of gonnardite is negative, and those of thomsonite and of natrolite are positive.

\section{INTRODUCTION}

The formulas for thomsonite and gonnardite, like those for natrolite, mesolite, and scolecite, suggest minerals of fixed and definite composition, although they are well known to be quite variable in composition. Winchell (1925) recognized that there is isomorphous $\mathrm{NaSi} \rightleftarrows \mathrm{CaAl}$ replacement in thomsonite, as between thomsonite, $\mathrm{Ca}_{2.0} \mathrm{Na}_{1.0} \mathrm{Al}_{5.0} \mathrm{Si}_{5.0} \mathrm{O}_{20} \cdot 6.0 \mathrm{H}_{2} \mathrm{O}$ and $\mathrm{Ca}_{1.25} \mathrm{Na}_{1.75} \mathrm{Al}_{4.25} \mathrm{Si}_{5.75} \mathrm{O}_{20} \cdot 5.0 \mathrm{H}_{2} \mathrm{O}$. Hey (1932) concurred with this view but considered that there is also considerable $\mathrm{Na}_{2} \rightleftharpoons \mathrm{Ca}$ replacement, which Winchell had considered unimportant. However Hey's formula for gonnardite, $2\left[\mathrm{Na}_{2} \mathrm{CaAl}_{4} \mathrm{Si}_{6} \mathrm{O}_{20} \cdot 7 \mathrm{H}_{2} \mathrm{O}\right]$, is related to thomsonite by $\mathrm{NaSi} \rightarrow \mathrm{CaAl}$ replacement only, although atomic ratios derived from analyses of gonnardite, including those published by Meixner, Hey, and Moss (1956), indicate both $\mathrm{NaSi} \rightarrow \mathrm{CaAl}$ and $\mathrm{Na}_{2} \rightarrow \mathrm{Ca}$ substitution.

The relation between $\mathrm{H}_{2} \mathrm{O}$ and the cations in thomsonite is less simple than in natrolite or mesolite. Taylor, Meek, and Jackson (1933) assume the environment of the $\mathrm{Na}$ ion and one of the $\mathrm{Ca}$ ions to be similar to that of the $\mathrm{Na}$ in natrolite, except for an additional $\mathrm{H}_{2} \mathrm{O}$ molecule that increases the coordination from sixfold to sevenfold with 4 oxygen ions and 3 water molecules. The other $\mathrm{Ca}$ ion they assume to be in eightfold coordination, with 6 oxygen ions and 2 water molecules. The relation between water molecules and cations is as though there were 1 water molecule for each $\mathrm{Na}$ ion, 2 for one-half of the $\mathrm{Ca}$ ions and 3 for the other half, or an average of 2.5 to 1 for all the Ca ions.

The water content of gonnardite seems to be in doubt. $\mathrm{Hey}$.(1955) gives the formula as $2\left[\mathrm{Na}_{2} \mathrm{CaAl}_{4} \mathrm{Si}_{6} \mathrm{O}_{20} \cdot 7 \mathrm{H}_{2} \mathrm{O}\right.$ ], but in 1956 Meixner, Hey, and Moss give the formula as $\left[(\mathrm{Ca}, \mathrm{Na})_{6-8}(\mathrm{Si}, \mathrm{Al})_{20} \mathrm{O}_{40} \cdot 12 \mathrm{H}_{2} \mathrm{O}\right]$, and Deer, Howie, and Zussman (1963 p. 359) give the formula as $\mathrm{Na}_{2} \mathrm{Ca}\left[(\mathrm{Al}, \mathrm{Si})_{5} \mathrm{O}_{10}\right]_{2} \cdot 6 \mathrm{H}_{2} \mathrm{O}$. These amounts of water seem high in a fibrous zeolite in which $\mathrm{Na}$ is the principal cation. In other fibrous zeolites in which $\mathrm{Na}$ is a 
principal cation-natrolite and mesolite-the ratio of $\mathrm{H}_{2} \mathrm{O}$ molecules to $\mathrm{Na}$ ions is $1: 1$, compared to the ratio of 3:1 or 2.5:1 for Ca-dominant zeolites like scolecite and thomsonite. As Na is the predominant cation in gonnardite, $\mathrm{H}_{2} \mathrm{O}$ would be expected to be lower in gonnardite than in thomsonite, rather than the same or higher as indicated by these formulas. It is significant that in the analyses of gonnardite given by Meixner, Hey, and Moss, the two having the highest $\mathrm{Na}$ content yield molecular ratios for $\mathrm{H}_{2} \mathrm{O}$ of only 5.14 and 5.19.

The purpose of this investigation is to study the degree and kind of variation in composition that occurs in the thomsonites and gonnardites, and the relation of these minerals to each other, and to examine the problem of the water content of gonnardite. The analyses of thomsonite used were selected from those reported or cited by Hey (1932), using only analyses published after 1885, in which the sum of the tetrahedral atoms was $10.0 \pm 0.10$. In addition to the analyses of gonnardite published by Meixner, Hey, and Moss, several other recent analyses from the literature were also used.

Atomic ratios were calculated from the analyses on the basis of 20 oxygen atoms, and represent, according to Hey's (1955, p. 166) formulas, quarter-cell values for thomsonites and half-cell values for gonnardites.

\section{THOMSONITE \\ $\mathrm{Na}_{1.0} \mathrm{Ca}_{2.0} \mathrm{Al}_{6.0} \mathrm{Si}_{5.0} \mathrm{O}_{20} \cdot 6.0 \mathrm{H}_{2} \mathrm{O}$}

Atomic ratios for selected post-1885 analyses of thomsonite reported or cited by Hey (1932) are given in tables 1 and 2 together with calculated values for $\mathrm{H}_{2} \mathrm{O}$. The atomic ratios show wide ranges in the values for $\mathrm{Si}$ and $\mathrm{Al}$. The ranges for $\mathrm{Ca}$ and $\mathrm{Na}$ are even greater, from 2.14 to 1.00 for $\mathrm{Ca}$, from 0.74 to 2.71 for $\mathrm{Na}$, and from 2.58 to 3.71 for $(\mathrm{Ca}+\mathrm{Na})$. However, $\mathrm{Ca}$ values greater than 2.00 are found in only four analyses and these values are 2.02, 2.04, 2.07, 2.14. Values for $\mathrm{Na}$ less than 1.00, were found in only seven; of these seven, only three, $0.89,0.88$, and 0.74 , are less than 0.90 . Both types of replacement recognized in thomsonite affect the $\mathrm{Ca}$ and $\mathrm{Na}$ content, consequently the kind and amount of replacement can be estimated only by other deviations in composition. A Si value greater than 5.00, the theoretical amount according to the above formula for thomsonite, together with an Al value deficient by about the same amount, indicates replacement of an equivalent amount of $\mathrm{Ca}$ by $\mathrm{Na}$. A positive difference in the expression $[(\mathrm{Ca}+\mathrm{Na})-3.00]$ indicates that this amount of $\mathrm{Ca}$ has been replaced by $\mathrm{Na}_{2}$; a negative result indicates the amount of $\mathrm{Ca}$ replacing $\mathrm{Na}_{2}$. The fact that in the ranges in $\mathrm{Ca}$ and $\mathrm{Na}$ quoted above most $\mathrm{Ca}$ values are less than 2.0 , with few significantly above, and that most $\mathrm{Na}$ values are greater than 1.00 , with few significantly less, indicates" that replace-
TABEE 1.-Atomic ratios calculated from analyses of thomsonite reported by Hey, 1932

[Numbers refer to Hey, 1932, table 1, p. 54-65]

\begin{tabular}{|c|c|c|c|c|c|c|c|c|}
\hline \multirow[b]{2}{*}{ No. } & \multirow[b]{2}{*}{$\mathrm{Ca}(+\mathrm{Mg})$} & \multirow[b]{2}{*}{$\mathrm{Na}(+\mathrm{K})$} & \multirow[b]{2}{*}{$(\mathrm{Ca}+\mathrm{Na})$} & \multirow[b]{2}{*}{ Al } & \multirow[b]{2}{*}{ S1 } & \multicolumn{3}{|c|}{$\mathrm{H}_{2} \mathrm{O}$} \\
\hline & & & & & & $\begin{array}{l}\text { Deter- } \\
\text { mined }\end{array}$ & $\begin{array}{l}\text { Calou- } \\
\text { lated }\end{array}$ & $\begin{array}{c}\text { Differ- } \\
\text { ence }\end{array}$ \\
\hline & $\begin{array}{l}1.62 \\
1.67 \\
1.84 \\
1.71 \\
1.00\end{array}$ & $\begin{array}{r}1.48 \\
1.20 \\
.74 \\
.89 \\
2.71\end{array}$ & $\begin{array}{l}3.10 \\
2.87 \\
2.58 \\
2.60 \\
3.71\end{array}$ & $\begin{array}{l}\text { 4. } 52 \\
\text { 4. } 57 \\
\text { 4. } 58 \\
\text { 4. } 62 \\
\text { 4. } 62\end{array}$ & $\begin{array}{l}5.43 \\
5.42 \\
5.46 \\
5.46 \\
5.36\end{array}$ & $\begin{array}{l}6.34 \\
5.58 \\
6.10 \\
6.44 \\
5.48\end{array}$ & $\begin{array}{l}\text { 5. } 53 \\
\text { 5. } 38 \\
\text { 5. } 34 \\
\text { 5. } 17 \\
5.21\end{array}$ & $\begin{array}{r}+0.81 \\
+.20 \\
+.76 \\
+1.27 \\
+.27\end{array}$ \\
\hline & $\begin{array}{l}1.41 \\
1.72 \\
1.76 \\
1.45 \\
1.82\end{array}$ & $\begin{array}{l}1.70 \\
1.18 \\
1.24 \\
1.71 \\
1.24\end{array}$ & $\begin{array}{l}3.11 \\
2.90 \\
3.00 \\
3.16 \\
3.06\end{array}$ & $\begin{array}{l}4.62 \\
4.65 \\
4.68 \\
4.70 \\
4.73\end{array}$ & $\begin{array}{l}5.40 \\
5.36 \\
5.29 \\
5.32 \\
5.23\end{array}$ & $\begin{array}{l}6.44 \\
5.50 \\
6.12 \\
5.46 \\
5.92\end{array}$ & $\begin{array}{l}5.22 \\
5.48 \\
5.64 \\
5.33 \\
5.79\end{array}$ & $\begin{array}{r}+1.22 \\
+.02 \\
+.48 \\
+.13 \\
+.13\end{array}$ \\
\hline & $\begin{array}{l}1.74 \\
1.98 \\
2.08 \\
1.98 \\
2.00\end{array}$ & $\begin{array}{r}1.26 \\
1.22 \\
.88 \\
.97 \\
1.04\end{array}$ & $\begin{array}{l}3.00 \\
\text { 3. } 20 \\
2.96 \\
2.95 \\
\text { 3. } 94\end{array}$ & $\begin{array}{l}4.78 \\
4.87 \\
4.90 \\
4.93 \\
\text { 5. } 03\end{array}$ & $\begin{array}{l}5.23 \\
5.06 \\
5.06 \\
5.07 \\
4.97\end{array}$ & $\begin{array}{l}5.89 \\
5.82 \\
6.10 \\
5.61 \\
5.95\end{array}$ & $\begin{array}{l}5.61 \\
6.17 \\
6.08 \\
5.92 \\
6.04\end{array}$ & $\begin{array}{r}+.28 \\
+.35 \\
+.02 \\
-.31 \\
-.09\end{array}$ \\
\hline & 2.02 & .94 & 2. 96 & 5.04 & 4. 98 & 6.17 & 5. 99 & +.18 \\
\hline
\end{tabular}

TABLE 2.-Atomic ratios calculated from selected post-1870 analyses of thomsonite cited by Hey, 1932

[Numbers refer to Hey, 1932, table 2, p. 58-64]

\begin{tabular}{|c|c|c|c|c|c|c|c|c|}
\hline \multirow[b]{2}{*}{ No. } & \multirow[b]{2}{*}{$\mathrm{Ca}(+\mathrm{Mg})$} & \multirow[b]{2}{*}{$\mathrm{Na}(+\mathrm{K})$} & \multirow[b]{2}{*}{$\because(\mathrm{Ca}+\mathrm{Na})$} & \multirow[b]{2}{*}{ Al } & \multirow[b]{2}{*}{$\mathrm{si}$} & \multicolumn{3}{|c|}{$\mathrm{H}_{2} \mathrm{O}$} \\
\hline & & & & & & $\begin{array}{l}\text { Deter- } \\
\text { mined }\end{array}$ & $\begin{array}{l}\text { Calcu- } \\
\text { lated }\end{array}$ & $\begin{array}{c}\text { Differ- } \\
\text { ence }\end{array}$ \\
\hline & $\begin{array}{l}1.59 \\
1.56 \\
1.94 \\
1.98 \\
1.96\end{array}$ & $\begin{array}{l}1.58 \\
1.30 \\
1.04 \\
1.10 \\
1.04\end{array}$ & $\begin{array}{l}3.17 \\
2.86 \\
2.98 \\
\text { 3. } 08 \\
\text { 3. } 00\end{array}$ & $\begin{array}{l}4.76 \\
\text { 4. } 64 \\
\text { 4. } 98 \\
\text { 5. } 06 \\
\text { 5. } 03\end{array}$ & $\begin{array}{l}\text { 5. } 24 \\
5.40 \\
5.04 \\
4.94 \\
4.98\end{array}$ & $\begin{array}{l}5.52 \\
5.42 \\
6.23 \\
6.00 \\
6.08\end{array}$ & $\begin{array}{l}5.56 \\
5.20 \\
5.89 \\
6.05 \\
5.94\end{array}$ & $\begin{array}{r}-0.04 \\
+.22 \\
+.34 \\
-.05 \\
+-.14\end{array}$ \\
\hline & $\begin{array}{l}1.92 \\
2.04 \\
1.84 \\
1.94 \\
1.94\end{array}$ & $\begin{array}{r}1.16 \\
1.01 \\
1.10 \\
1.10 \\
.91\end{array}$ & $\begin{array}{l}3.08 \\
3.05 \\
2.94 \\
3.04 \\
2.85\end{array}$ & $\begin{array}{l}4.78 \\
5.02 \\
4.80 \\
4.95 \\
4.93\end{array}$ & $\begin{array}{l}5.16 \\
4.91 \\
5.20 \\
5.05 \\
5.11\end{array}$ & $\begin{array}{l}6.03 \\
6.05 \\
5.98 \\
5.81 \\
5.73\end{array}$ & $\begin{array}{l}5.96 \\
6.11 \\
5.70 \\
5.95 \\
5.76\end{array}$ & $\begin{array}{l}+.07 \\
+.06 \\
+.28 \\
-.14 \\
-.03\end{array}$ \\
\hline $\begin{array}{l}66 \\
69 \\
71 \\
72\end{array}$ & $\begin{array}{l}1.18 \\
1.58 \\
1.64 \\
1.68 \\
1.73\end{array}$ & $\begin{array}{l}2.18 \\
1.62 \\
1.30 \\
1.06 \\
1.06\end{array}$ & $\begin{array}{l}\text { 3. } 36 \\
\text { 3. } 20 \\
\text { 2. } 94 \\
2.74 \\
\text { 2. } 79\end{array}$ & $\begin{array}{l}4.67 \\
4.72 \\
4.57 \\
4.78 \\
4.83\end{array}$ & $\begin{array}{l}\text { 5. } 37 \\
5.26 \\
5.43 \\
5.22 \\
5.24\end{array}$ & $\begin{array}{l}6.54 \\
5.08 \\
5.84 \\
5.64 \\
5.71\end{array}$ & $\begin{array}{l}5.13 \\
5.57 \\
5.40 \\
5.26 \\
5.38\end{array}$ & $\begin{array}{r}+1.41 \\
+.49 \\
+.44 \\
+.38 \\
+.33\end{array}$ \\
\hline $\begin{array}{l}78 . \\
79 .\end{array}$ & $\begin{array}{l}1.68 \\
1.68 \\
1.54 \\
1.60 \\
1.59\end{array}$ & $\begin{array}{l}1.21 \\
1.14 \\
1.24 \\
1.43 \\
1.36\end{array}$ & $\begin{array}{l}2.89 \\
2.82 \\
2.78 \\
3.03 \\
2.95\end{array}$ & $\begin{array}{l}4.62 \\
4.68 \\
4.50 \\
4.60 \\
4.60\end{array}$ & $\begin{array}{l}5.40 \\
5.36 \\
5.56 \\
5.39 \\
5.42\end{array}$ & $\begin{array}{l}5.68 \\
55.66 \\
5.34 \\
5.68 \\
5.77\end{array}$ & $\begin{array}{l}5.41 \\
5.34 \\
5.09 \\
5.43 \\
5.34\end{array}$ & $\begin{array}{r}+.27 \\
+.32 \\
+.25 \\
+.25 \\
+.43\end{array}$ \\
\hline $\begin{array}{l}92 \mathrm{a} \\
94 \\
95 \\
100\end{array}$ & $\begin{array}{l}2.14 \\
1.97 \\
1.74 \\
1.64\end{array}$ & $\begin{array}{l}.95 \\
1.04 \\
1.05 \\
1.50\end{array}$ & $\begin{array}{l}\text { 3. } 09 \\
\text { 3. } 01 \\
2.79 \\
\text { 3. } 14\end{array}$ & $\begin{array}{l}\text { 5. } 02 \\
4.98 \\
4.96 \\
4.61\end{array}$ & $\begin{array}{l}\text { 4. } 92 \\
5.02 \\
5.02 \\
5.36\end{array}$ & $\begin{array}{l}\text { 6. } 24 \\
\text { 5. } 90 \\
\text { 5. } 79 \\
\text { 5. } 59\end{array}$ & $\begin{array}{l}\text { 6. } 30 \\
5.96 \\
5.40 \\
\text { 5. } 60\end{array}$ & $\begin{array}{r}-.06 \\
-.06 \\
+.39 \\
-.01\end{array}$ \\
\hline
\end{tabular}

ment of $\mathrm{Ca}$ by $\mathrm{Na}$, by one method or the other, greatly predominates over the reverse and that replacement of $\mathrm{Na}$ by $\mathrm{Ca}$ is of relatively little importance in the thomsonites.

The atomic ratios yielded by some analyses of thomsonites are so close to the theoretical values that little replacement of either type is indicated. For example, in No. 15, table 1, none of the atomic ratios deviate more than 0.04 from the theoretical values, and the molecular value for $\mathrm{H}_{2} \mathrm{O}$ is 5.95 as compared with 6.00 . Other analyses whose atomic ratios, given in tables 1 and 2, are very close to the theoretical values, are Nos. $14,16,32,33,45,49$, and 94 . The $\mathrm{Si}, \mathrm{Al}$, and $(\mathrm{Ca}+\mathrm{Na})$ values for all the other analyses whose atomic ratios are given in tables 1 and 2 indicate both types of replace- 
ment, except for Nos. 8, 11, and 81 . In these replacement of $\mathrm{CaAl}$ by $\mathrm{NaSi}$ is indicated; the $(\mathrm{Ca}+\mathrm{Na})$ values of 3.00 and 3.03 indicating that no $\mathrm{Na}_{2} \rightleftharpoons \mathrm{Ca}$ replacement has occurred.

In almost all the analyses in which both types of replacement are indicated, the $\mathrm{Si}$ value is usually greater than 5.00 and the $\mathrm{Al}$ value is less, indicating that replacement of $\mathrm{CaAl}$ by $\mathrm{NaSi}$ is more common in thomsonites than replacement of $\mathrm{NaSi}$ by $\mathrm{CaAl}$. With respect to $\mathrm{Na}_{2} \rightleftharpoons \mathrm{Ca}$ replacement, 17 of the 40 $(\mathrm{Ca}+\mathrm{Na})$ values in tables 1 and 2 are greater than 3.00 , indicatng replacement of $\mathrm{Ca}$ by $\mathrm{Na}_{2}$, and 20 are less than 3.00, indicating replacement of $\mathrm{Na}_{2}$ by Ca. As in most thomsonites replacements of the $\mathrm{NaSi} \rightleftharpoons \mathrm{CaAl}$ type are of $\mathrm{NaSi}$ for CaAl. Thus in some there is dual replacement by $\mathrm{Na}$, but in others there is both replacement of $\mathrm{CaAl}$ by $\mathrm{NaSi}$ and replacement of $\mathrm{Na}_{2}$ by $\mathrm{Ca}$, with the replacements offsetting each other to greater or less degree. Although the thomsonites whose atomic ratios are given in tables 1 and 2 differ widely in content of $\mathrm{Ca}$ and $\mathrm{Na}$, the sum of the atomic ratios for $\mathrm{Ca}$ and $\mathrm{Na},(\mathrm{Ca}+\mathrm{Na})$ is quite constant, $3.00 \pm 0.20$ in all but eight of the analyses (Nos. 3, 4, 5, 66, 72, 76, 80, and 95). In Nos. 76 and 80 the difference is only 0.21 and 0.22 , respectively.

The relation between $\mathrm{Ca}$ and $\mathrm{Na}$ in thomsonites is shown graphically in figure 1 . The points representing thomsonites whose atomic ratios for $\mathrm{Ca}$ and $\mathrm{Na}$ are close to the theoretical 2.00 and 1.00 , respectively, cluster closely around the asterisk that represents theoretical thomsonite. A few points fall a very short way along the line representing $\mathrm{Na}_{2} \rightarrow \mathrm{Ca}$ replacement, but more fall along or below the line representing $\mathrm{NaSi}$ replacement of $\mathrm{CaAl}$. However, none fall as far along this line as the asterisk representing theoretical faroelite. Even the point representing the average $\mathrm{Ca}$ and $\mathrm{Na}$ ratios for the five Faroe Islands zeolites cited by Hey (1932)-Nos. 19, 21, 22, 23, and 24a-fall short of this point. Farther out along this line is the point representing the "gonnardite" calculated by Hey (1932) from an analysis of a spherulite made up of thomsonite and gonnardite. The points that fall below the $\mathrm{NaSi} \rightarrow \mathrm{CaAl}$ replacement line represent thomsonites in which replacement of $\mathrm{CaAl}$ by $\mathrm{NaSi}$ is accompanied by some replacement of $\mathrm{Na}_{2}$ by $\mathrm{Ca}$. Most of the points representing the Table Mountain, Colo., thomsonites (Nos. 78, 79, 80, 81, and 83, table $2)$, fall in this area.

The points representing the relation between $\mathrm{Ca}$ and $\mathrm{Na}$ in thomsonites that have the highest $\mathrm{Na}$ content (Nos. 5, 9, 24a, 66, and 69) fall along a line between the $\mathrm{Na}_{2} \rightarrow \mathrm{Ca}$ replacement and the $\mathrm{NaSi} \rightarrow \mathrm{CaAl}$ replacement lines. This middle line represents dual replacement: replacement of $\mathrm{Ca}$ by $\mathrm{Na}_{2}$ and of $\mathrm{Ca}$ as

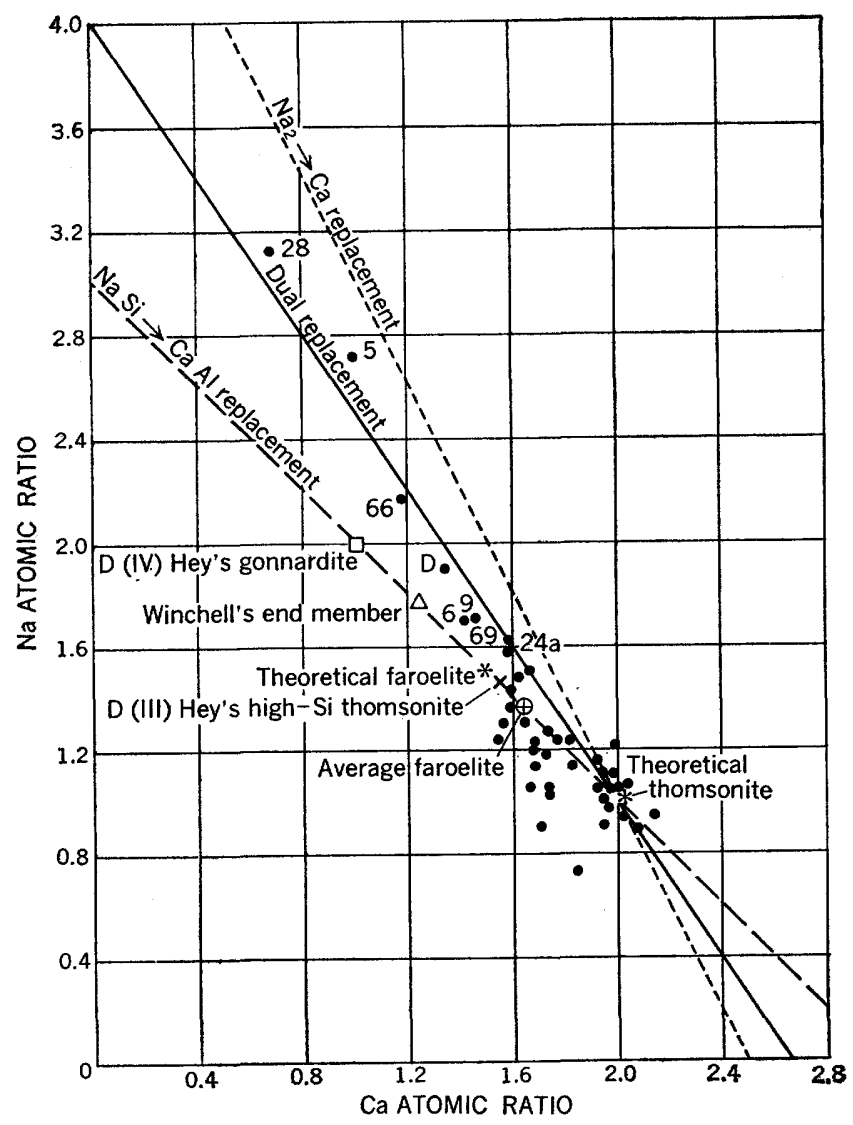

Frgure 1.-Relation between $\mathrm{Ca}$ and $\mathrm{Na}$ in thomsonites.

$\mathrm{CaAl}$ by $\mathrm{NaSi}$ to the same degree. The highest $\mathrm{Na}$ ratio in tables 1 and 2 is that in analysis 5 , but the highest $\mathrm{Na}$ ratio in the analyses cited by Hey (1932) is in analysis 28 . The value he gives, 12.50 , is for the unit cell, which would be 3.125 in terms of the quarter cell as used in this study. In the same terms the ratio for $\mathrm{Ca}$ is only 0.68 . The point representing the relation between $\mathrm{Ca}$ and $\mathrm{Na}$ in this analysis falls considerably farther along the dual replacement line than does the point representing No. 5 which actually falls between the dual replacement line and the $\mathrm{Na}_{2} \rightarrow \mathrm{Ca}$ line. Analysis 28 is cited by Hey as that of a thomsonite. although it had been earlier considered to be that of a mesolite. It was not included in table 2 because of its age (1836).

The relation between $\mathrm{Ca}$ and $\mathrm{H}_{2} \mathrm{O}$ in thomsonites is shown graphically in figure 2. Although thomsonites that have the same $\mathrm{Ca}$ ratio may differ greatly in $\mathrm{H}_{2} \mathrm{O}$ content, the points in figure 2 do show a general downward trend in $\mathrm{H}_{2} \mathrm{O}$ content with decrease in Ca. In general, analyses having high $\mathrm{Ca}$ contents tend to have high $\mathrm{H}_{2} \mathrm{O}$ contents, and analyses having low $\mathrm{Ca}$ contents tend to have low $\mathrm{H}_{2} \mathrm{O}$ contents, except for analyses $1,4,6$, and 66 , in which $\mathrm{H}_{2} \mathrm{O}$ is very high. The points representing these analyses fall completely outside the pattern made by the other points. 


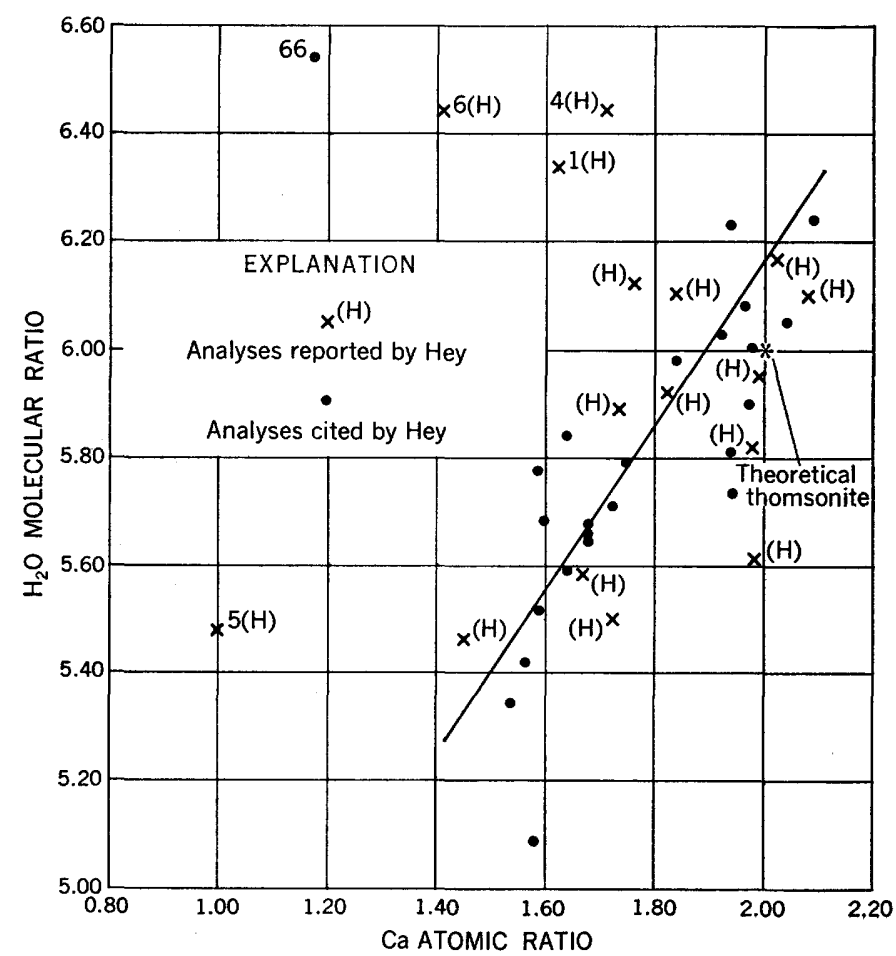

Figure 2.- Relation between $\mathrm{Ca}$ and $\mathrm{H}_{2} \mathrm{O}$ in thomsonites.

\section{GONNARDITE}

$\mathrm{Na}_{2.0} \mathrm{Ca}_{1.0} \mathrm{Al}_{4.0} \mathrm{Si}_{6.0} \mathrm{O}_{20} \cdot 7 \mathrm{H}_{2} \mathrm{O}$

Five analyses of gonnardite were published by Meixner, Hey, and Moss (1956), including two (D and
E) that Hey had published in 1932 as an analyses of gonnardite-thomsonite spherules. The outer part of the spherules was described as thomsonite, and the inner part as gonnardite. When the analyses were republished as analyses of gonnardite, no explanation was given as to why analyses originally published as analyses of a composite sample were republished 24 years later as analyses of a single mineral. In $1932 \mathrm{Hey}$ had prorated the constituents found in these analyses between a high-silica thomsonite and hypothetical gonnardite on the basis of assumed compositions and of the proportion of each estimated to be present in the spherule analyzed. The half-cell atomic ratios for this calculated gonnardite, $\mathrm{D}(\mathrm{IV})$, are given in table 3 . Also given in table 3 with their atomic ratios, are analyses A, B, C, and D of Meixner, Hey, and Moss (1956), two other analyses of gonnardite from the literature, and three recent analyses of high-Na mesolite. The Bulgarian material (Kostov, 1958) analyzed was called "gonnardite (with thomsonite?)." The analysis of the material from Norway is an old one by Paijkull (1874). This material was originally called ranite, but Mason (1957) recently identified it as gonnardite. The analyses of high-Na mesolites given in the last three columns of table 3 indicate compositions very similar to that of gonnardite or high $\mathrm{Na}$ thomsonite.

The relation between the atomic ratios of $\mathrm{Ca}$ and $\mathrm{Na}$ given in table 2 is shown graphically in figure 3. Also shown in figure 3 is the relation between $\mathrm{Ca}$ and $\mathrm{Na}$ in

$\mathrm{T}_{\mathrm{ABLE}}$ 3.- Analyses of gonnardites and high-Na mesolites, and their atomic ratios

[In order of increasing $\mathrm{Na}_{2} \mathrm{O}$ content]

\begin{tabular}{|c|c|c|c|c|c|c|c|c|c|c|}
\hline & \multicolumn{7}{|c|}{ Gonnardites } & \multicolumn{3}{|c|}{ High-Na mesolites } \\
\hline & $\mathrm{D}$ & $\mathrm{D}(\mathrm{IV})$ & $\mathbf{C}$ & 1 & 2 & $\mathbf{A}$ & $\mathbf{B}$ & 3 & 4 & 5 \\
\hline \multicolumn{11}{|c|}{ Composition (percent) } \\
\hline $\begin{array}{l}\mathrm{SiO}_{2} \\
\mathrm{Al}_{2} \mathrm{O}_{3} \\
\mathrm{CaO}_{2} \mathrm{~N}_{2} \mathrm{O}_{2} \\
\mathrm{~K}_{2} \mathrm{O}_{2} \\
\mathrm{H}_{2} \mathrm{O}\end{array}$ & $\begin{array}{r}41.85 \\
27.02 \\
9.29 \\
7.25 \\
\text { n.d. } \\
14.37 \\
99.78\end{array}$ & 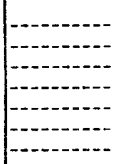 & $\begin{array}{r}42.75 \\
27.36 \\
7.77 \\
8.15 \\
.15 \\
13.44 \\
99.62\end{array}$ & $\begin{array}{r}42.71 \\
30.16 \\
6.25 \\
9.50 \\
111.70 \\
8100.50\end{array}$ & \begin{tabular}{r|}
39.21 \\
31.79 \\
5.07 \\
11.55 \\
11.71 \\
199.90
\end{tabular} & \begin{tabular}{r|}
42.80 \\
28.15 \\
4.26 \\
12.65 \\
11.13 \\
99.84
\end{tabular} & $\begin{array}{r}43.20 \\
27.90 \\
3.61 \\
13.16 \\
\text { Trace } \\
11.74 \\
99.61\end{array}$ & $\begin{array}{r}40.03 \\
27.88 \\
6.03 \\
10.05 \\
2.40 \\
211.10 \\
5100.29\end{array}$ & $\begin{array}{r}41.15 \\
29.49 \\
5.33 \\
11.02 \\
.25 \\
13.52 \\
100.76\end{array}$ & $\begin{array}{r}40.59 \\
29.69 \\
5.06 \\
11.00 \\
.51 \\
13.58 \\
100.43\end{array}$ \\
\hline \multicolumn{11}{|c|}{ Atoms per half cell ( 20 oxygens) } \\
\hline $\begin{array}{l}\mathrm{Si} \\
\mathrm{Al} \\
(\mathrm{Ca}+\mathrm{Mg}) \\
(\mathrm{Na}+\mathrm{K}) \\
(\mathrm{Ca}+\mathrm{Na}) \\
\mathrm{H}_{2} \mathrm{O} \text { (determined) } \\
\mathrm{H}_{2} \mathrm{O} \text { (calculated) } \\
\text { Difference. }\end{array}$ & \begin{tabular}{r|}
5.64 \\
4.29 \\
1.34 \\
1.89 \\
3.23 \\
6.46 \\
5.91 \\
+.55
\end{tabular} & 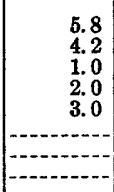 & $\begin{array}{r}5.69 \\
4.29 \\
1.11 \\
2.12 \\
3.23 \\
5.97 \\
5.45 \\
+.54\end{array}$ & $\begin{array}{r}5.52 \\
4.59 \\
3.90 \\
2.37 \\
3.27 \\
4.85 \\
5.07 \\
-.22\end{array}$ & \begin{tabular}{r|}
5.18 \\
4.95 \\
.72 \\
2.96 \\
3.68 \\
5.16 \\
5.12 \\
+.04
\end{tabular} & $\begin{array}{r}5.62 \\
4.36 \\
.60 \\
3.24 \\
3.84 \\
5.19 \\
5.04 \\
+.15\end{array}$ & $\begin{array}{r}5.67 \\
4.32 \\
.51 \\
3.35 \\
3.86 \\
5.14 \\
4.88 \\
+.26\end{array}$ & $\begin{array}{r}5.48 \\
4.50 \\
.92 \\
2.73 \\
5.65 \\
5.07 \\
5.49 \\
-.42\end{array}$ & $\begin{array}{r}5.45 \\
4.60 \\
.76 \\
2.86 \\
3.62 \\
5.97 \\
5.14 \\
+.83\end{array}$ & $\begin{array}{r}5.41 \\
4.66 \\
.72 \\
2.92 \\
3.64 \\
6.03 \\
5.08 \\
+.05\end{array}$ \\
\hline \multicolumn{11}{|c|}{$\begin{array}{l}\text { "Includes } 0.57 \mathrm{Fe}_{2} \mathrm{O}_{3} \text {. } \\
\text { Includes } 0.85 \mathrm{Fe}_{2} \mathrm{O}_{3}, 0.59 \mathrm{FeO}, 0.22 \mathrm{MgO}\left(0.04 \mathrm{Mg} \text { atomic ratio) and } 0.02 \mathrm{TiO}_{2} .\right.\end{array}$} \\
\hline \multicolumn{11}{|c|}{$\begin{array}{lc}\qquad \text { LOCALITY AND REFERENCE } & \text { FOR ANALYSES IN TABLE } 7 \\
\text { ar, Hey, and Moss, 1956, p. 266. } & \text { A. Klöck, Styria, Meixner, Hey, and Moss, 1956, p. } 266 . \\
\text { nnardite, calculated by Hey (1932, p. 117) } & \text { B. Aci Trezza, Sicily, Meixner, Hey, and Moss, 1956, p. } 266 . \\
\text { and Moss, 1956, p. } 266 . & \text { 3. Rio Cambone, Montiferro, Sardinia, Deriu, 1954, p. } 42 . \\
\text { p. 16, no. 1. } & \text { 4, 5. Kladno, Bohemia, Antonin, 1942, p. 11. }\end{array}$} \\
\hline
\end{tabular}




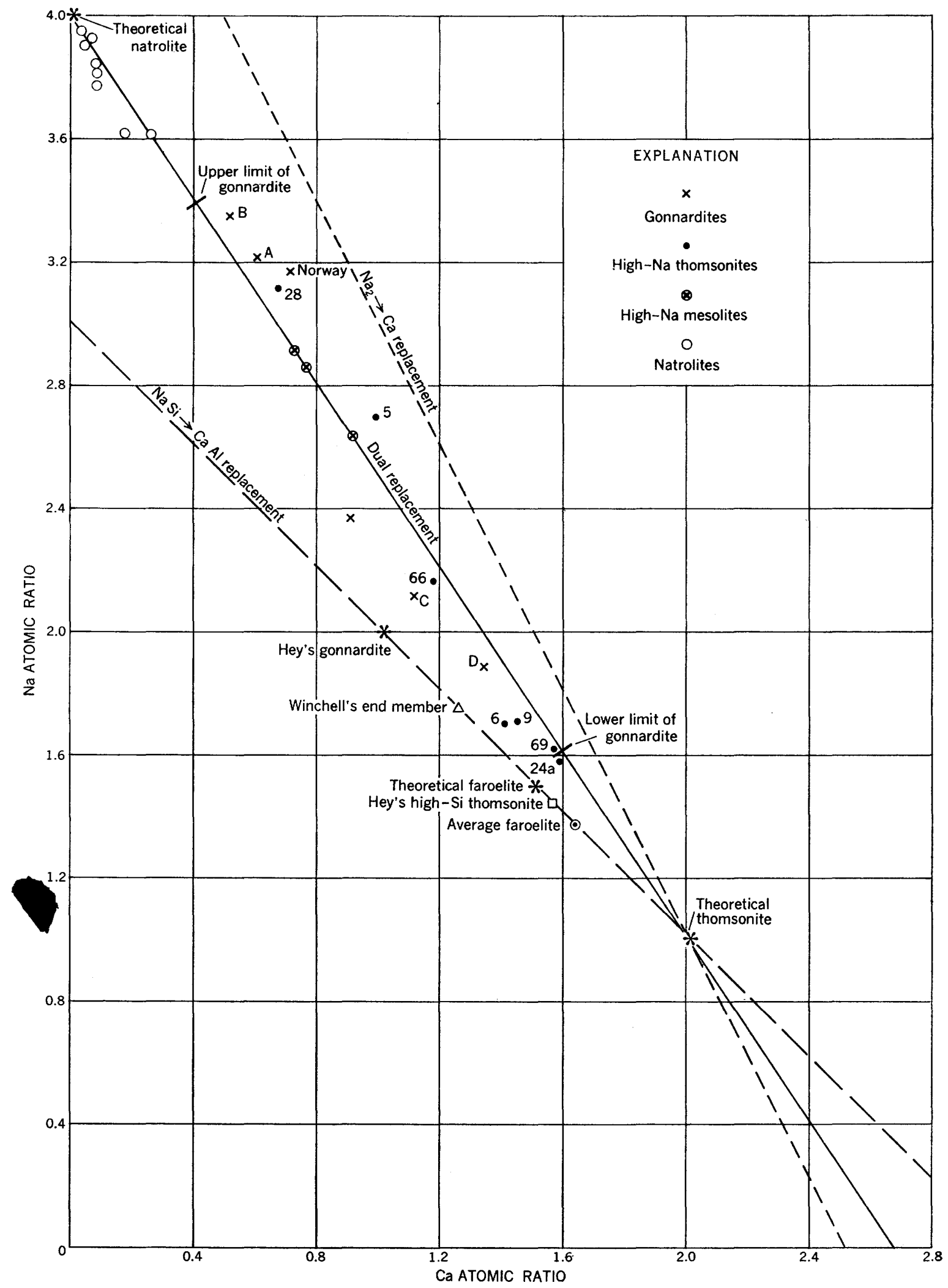

Figure 3.-Relation between $\mathrm{Ca}$ and $\mathrm{Na}$ in gonnardites, and high-Na thomsonites and mesolites. 
the high-Na thomsonites given in tables 5 and 6 , Nos. 1, 5, 6, 9, 24a, and 66. The relation between $\mathrm{Ca}$ and $\mathrm{Na}$ in $\mathrm{No} .28$, which had the highest $\mathrm{Na}$ content of the thomsonites cited by Hey (1932), is also shown in figure 4 . The material represented by this analysis had previously been called mesolite. The points representing gonnardites intermingle with points representing high-Na thomsonites and mesolites, and all the points fall close to and along the line representing dual replacement, in equal amounts, of $\mathrm{Ca}$ by $\mathrm{Na}_{2}$ and $\mathrm{Ca}$ as $\mathrm{CaAl}$ by NaSi. On the other hand, the point representing the relation between $\mathrm{Ca}$ and $\mathrm{Na}$ in the gonnardite $\mathrm{D}(\mathrm{IV})$, calculated by Hey from analysis $\mathrm{D}$ falls on the line representing $\mathrm{NaSi} \rightarrow \mathrm{CaAl}$ replacement at a point equivalent to 50 percent replacement of the $\mathrm{Ca}$ in thomsonite as $\mathrm{CaAl}$, and a step beyond the point representing theoretical faroelite, which is equivalent to a replacement of 25 percent of the $\mathrm{Ca}$ in thomsonite as CaAl. The point representing the thomsonite calculated by $\mathrm{Hey}, \mathrm{D}$ (III), also falls on the $\mathrm{NaSi} \rightarrow \mathrm{CaAl}$ replacement line a little below the point representing theoretical faroelite. Thus the points for "gonnardite" and "thomsonite" calculated by Hey from analysis $\mathrm{D}$ both fall on the $\mathrm{NaSi} \rightarrow \mathrm{CaAl}$ replacement line, whereas the point representing $D$ itself falls much closer to the line representing dual replacement.

The intermingling of points representing the relation between $\mathrm{Ca}$ and $\mathrm{Na}$ in gonnardites, high-Na thomsonites, and so-called mesolites along the line representing dual replacement of $\mathrm{Ca}$ in thomsonite suggest that all these zeolites may belong to an isomorphous series characterized by dual $\mathrm{NaSi} \rightarrow \mathrm{CaAl}$ and $\mathrm{Na}_{2} \rightarrow \mathrm{Ca}$ replacement, and that theoretical thomsonite, $\mathrm{Ca}_{2.0} \mathrm{Na}_{1.0} \mathrm{Al}_{5.0} \mathrm{Si}_{5.0} \mathrm{O}_{20} \cdot 6.0 \mathrm{H}_{2} \mathrm{O}$, is the high $\mathrm{Ca}$ end member of this series.

\section{A THOMSONITE-GONNARDITE-NATROLITE ISOMORPHOUS SERIES?}

Gonnardites and high-Na thomsonites can both be interpreted as derived from normal thomsonsite by dual replacement, to about the same degree of $\mathrm{Ca}$ by $\mathrm{Na}_{2}$, and of $\mathrm{CaAl}$ by NaSi. Steps in this dual replacement, starting with thomsonite, are shown in these formulas.

$$
\begin{aligned}
\text { Thomsonite: } & \mathrm{Na}_{1.0} \mathrm{Ca}_{2.0} \mathrm{Al}_{5.0} \mathrm{Si}_{5.0} \mathrm{O}_{20} \cdot 6.0 \mathrm{H}_{2} \mathrm{O} \\
& \mathrm{Na}_{1.75} \mathrm{Ca}_{1.50} \mathrm{Al}_{4.75} \mathrm{Si}_{5.25} \mathrm{O}_{20} \cdot 5.5 ? \mathrm{H}_{2} \mathrm{O} \\
& \mathrm{Na}_{2.50} \mathrm{Ca}_{1.00} \mathrm{Al}_{4.50} \mathrm{Si}_{6.50} \mathrm{O}_{20} \cdot 5.0 ? \mathrm{H}_{2} \mathrm{O} \\
& \mathrm{Na}_{3.25} \mathrm{Ca}_{0.50} \mathrm{Al}_{4.25} \mathrm{Si}_{5.75} \mathrm{O}_{20} \cdot 4.5 ? \mathrm{H}_{2} \mathrm{O} \\
\text { Natrolite: }: & \mathrm{Na}_{4.00} \mathrm{Ca}_{0.00} \mathrm{Al}_{4.00} \mathrm{Si}_{6.00} \mathrm{O}_{20} \cdot 4.0 \mathrm{H}_{2} \mathrm{O}
\end{aligned}
$$

The atomic ratios for No. 9 , table 1 , are very similar to those in the second formula, which represents the first step in the replacement. The atomic ratios for the analyses of gonnardite from Bulgaria and the highNa mesolite from Sardinia, table 3, are similar to those in the third formula, and the atomic ratios for analysis $\mathrm{A}$ and $\mathrm{B}$, table 3, are similar to those in the fourth formula. The Ca-free end member is identical with the formula for natrolite. Points representing the relation between $\mathrm{Ca}$ and $\mathrm{Na}$ in several natrolite analyses, Nos. 12, 15, 17, 22, and 25 (table 1), fall on or close to the upper end of the line representing dual replacement in figure 3 . The gonnardite $(\mathrm{B}$, table 3 ) having the highest $\mathrm{Na}$ content has a $\mathrm{Na}$ atomic ratio only 0.26 below the $\mathrm{Na}$ atomic ratio in the natrolite having the highest $\mathrm{Ca}$ content (No. 25, table 1). The formulas for these two analyses are:

\section{Analysis B, table 3: $\mathrm{Na}_{3.35} \mathrm{Ca}_{.51} \mathrm{Al}_{4.32} \mathrm{Si}_{6.67} \mathrm{O}_{20} \cdot 5.14 \mathrm{H}_{2} \mathrm{O}$ \\ Analysis 25, table 1: $\mathrm{Na}_{3.61} \mathrm{Ca}_{.27} \mathrm{Al}_{4.28} \mathrm{Si}_{5.77} \mathrm{O}_{20} \cdot 4.37 \mathrm{H}_{2} \mathrm{O}$}

The sum of the cations $(\mathrm{Ca}+\mathrm{Na})$ also agrees closely, 3.86 and 3.88 in $\mathrm{B}$ and No. 25, respectively.

The high-Na mesolites given in table 3 may be interpreted as either derived from thomsonite by replacement of $0.40-0.50 \mathrm{CaAl}$ by $0.40-0.50 \mathrm{NaSi}$, plus replacement of $0.60-0.65 \mathrm{Ca}$ by $1.20-1.30 \mathrm{Na}_{2}$, or as derived from mesolite by replacement of about

\begin{tabular}{|c|c|c|c|c|}
\hline & $\begin{array}{l}\text { Optic } \\
\text { axial } \\
\text { sign }\end{array}$ & $\alpha$ & $\boldsymbol{\beta}$ & $\boldsymbol{\gamma}$ \\
\hline \multirow{2}{*}{$\begin{array}{l}\text { Thomsonite-_. } \\
\text { Gonnardite } \\
\text { Natrolite. } \\
\text { Mesolite_. }\end{array}$} & + & 1. $497-1.530$ & 1. 513-1. 533 & \multirow{2}{*}{$\begin{array}{l}1.518-1.544 \\
1.499-1.508 \\
1.485-1.496 \\
\end{array}$} \\
\hline & \pm & 1. $473-1.483$ & $\begin{array}{l}\text { 1. } 476-1.486 \\
1.504-1.508\end{array}$ & \\
\hline
\end{tabular}
$0.50 \mathrm{CaSi}$ by an equivalent amount of $\mathrm{Na}_{3} \mathrm{Al}$.

Deer, Howie, and Zussman (1963, p. 358-359) give the following ranges in indices of refraction for thomsonite, gonnardite, natrolite, and mesolite:

\begin{tabular}{|c|c|c|c|c|}
\hline Analysis & $\alpha$ & $B$ & $\gamma$ & Source \\
\hline \multicolumn{5}{|c|}{ High-Na thomsonites } \\
\hline $\begin{array}{l}1 \\
5 \\
6 \\
9 \\
94 a-\end{array}$ & $\begin{array}{l}1.511 \\
1.523 \\
1.518 \\
1.517 \\
1.521\end{array}$ & $\begin{array}{l}\text { 1. } 513 \\
\text { 1. } 525 \\
\text { 1. } 520 \\
1.519 \\
1.523\end{array}$ & $\begin{array}{l}1.518 \\
1.527 \\
1.528 \\
1.526 \\
1.528\end{array}$ & $\begin{array}{l}\text { Hey, 1932, p. } 54 . \\
\text { Do. } \\
\text { Do. } \\
\text { Do. } \\
\text { Hey, 1932, p. } 80 .\end{array}$ \\
\hline \multicolumn{5}{|c|}{ Gonnardites and high-Na mesolites } \\
\hline $\begin{array}{l}\text { A } 1 \\
\text { B } 1 \\
\text { C } 1 \\
\text { D } 1 \text { Norway } 1 \\
\text { Sardinia }\end{array}$ & $\begin{array}{l}\text { 1. } 498 \\
\text { 1. } 497 \\
\text { 1. } 506 \\
1.506 \\
1.513 \\
1.5044\end{array}$ & - 1.052 & $\begin{array}{l}\text { 1. } 502 \\
\text { 1. } 499 \\
\text { 1. } 508 \\
\text { 1. } 508 \\
1.515 \\
\text { 1. } 5067\end{array}$ & $\begin{array}{l}\text { Meixner, Hey, and Moss, 1956, p. } 266 . \\
\text { Do. } \\
\text { Do. } \\
\text { Do. } \\
\text { Mason, } 1956 . \\
\text { Deriu, } 1954 .\end{array}$ \\
\hline
\end{tabular}

The following data are available on sor digh-Na thomsonites whose analyses are given in tables 1 and 2 and on the gonnardites and the high-Na mesolites whose analyses are given in table 3 :

1 The indices of refraction given are not true $\alpha$ and true $\gamma$, but $\alpha^{\prime}$ and $\gamma^{\prime}$. 


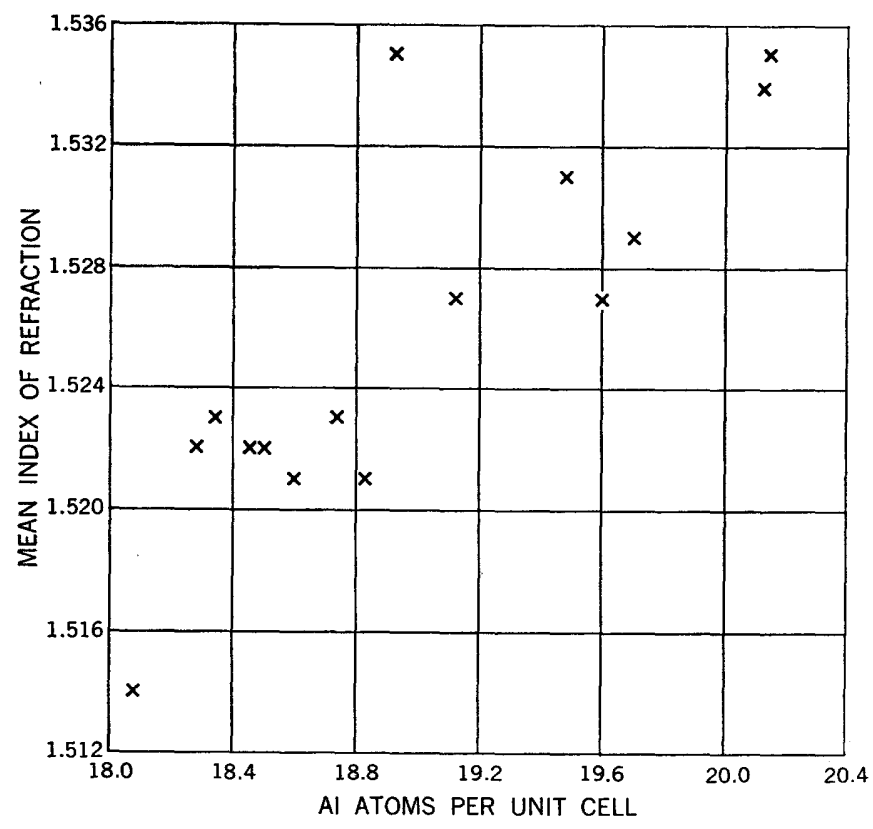

Figure 4. Relation between $\mathrm{Al}$ atoms per unit cell and mean index of refraction in thomsonites.

Hey (1932) found that the indices of refraction of thomsonite increase with increase in $\mathrm{Al}$, but are little affected by replacement of $\mathrm{Ca}$ by $\mathrm{Na}_{2}$, or vice versa. The relation between $\mathrm{Al}$ atoms and $\mathrm{Na}$ atoms per unit cell and the mean index of refraction in 16 thomsonites whose analyses were reported by Hey (1932) are shown in figures 4 and 5 . The general trend of the points in figure 4 is upward with increase in Al content and mean index of refraction, but the relation is not precise, as some thomsonites having the same $\mathrm{Al}$ content may differ considerably in mean index of refraction and vice versa. The location of the points in figure 5 indicates little relation between $\mathrm{Na}$ content and mean index of refraction. For example, six thomsonites having about the same number of $\mathrm{Na}$ atoms per unit cell, 4.74 to 5.04 , range in mean index of refraction from 1.521 to 1.535 . Thus the wide ranges in the indices of refraction of thomsonite seem to reflect the wide range in $\mathrm{Al}$ content, or conversely, $\mathrm{Si}$ content, in thomsonites, rather than variations in $\mathrm{Na}$ content or Ca content.

Gonnardites are characterized by varying $\mathrm{NaSi} \rightarrow$ $\mathrm{CaAl}$ and $\mathrm{Na}_{2} \rightarrow \mathrm{Ca}$ replacement, and should vary considerably in $\mathrm{Al}$ content, and, presuming the same relation as in thomsonite, in indices of refraction. The ranges in the indices of refraction for gonnardite given by Deer, Howie, and Zussman are coextensive with the ranges for prime $\left({ }^{\prime}\right)$ indices of refraction of gonnardite reported by Meixner, Hey, and Moss (1956), and are presumably based on them. Thus the ranges given by Deer, Howie, and Zussman for the indices of

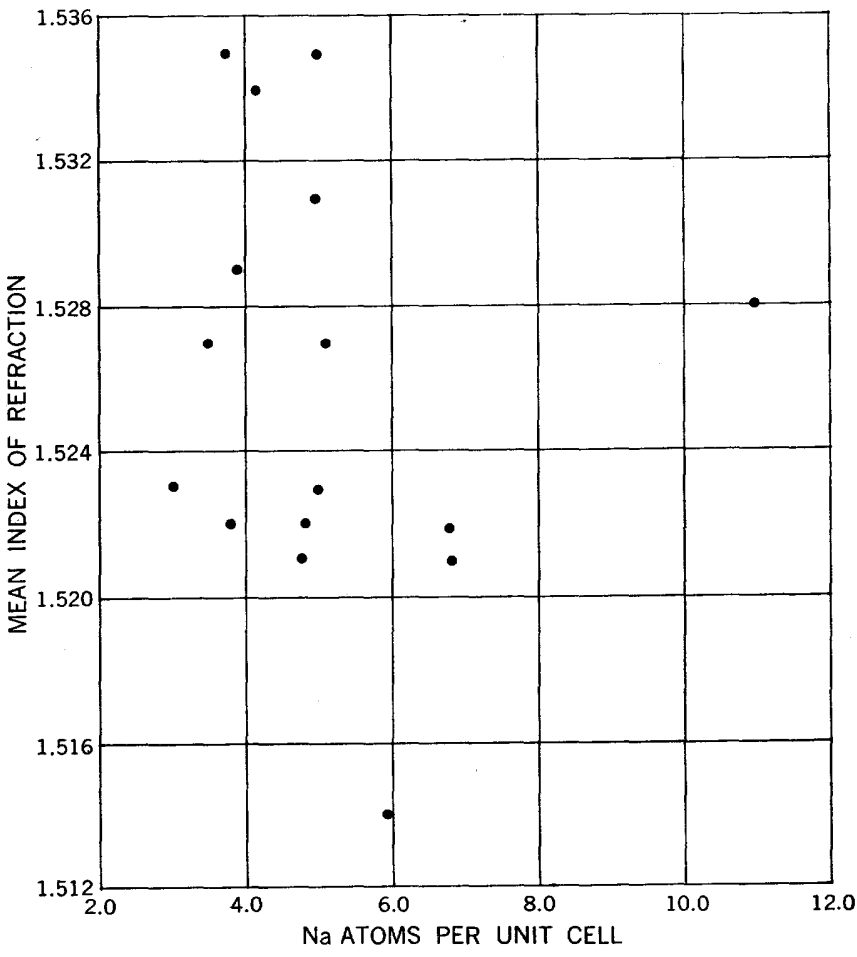

Figure 5. Relation between Na atoms per unit cell and mean index of refraction in thomsonites.

refraction of gonnardite are based on four sets of $\alpha^{\prime}$ and $\gamma^{\prime}$ values. Although these four gonnardites vary widely in $\mathrm{Na}$ content, from 1.89 to 3.35 atoms per half cell, they are very similar in $\mathrm{Al}$ content, varying only between 4.29 and 4.36 atoms. This is because in $\mathrm{D}$ and $\mathrm{C}$, which have the lower $\mathrm{Na}$ contents, 1.89 and 2.12 atoms per half cell, replacement of CaAl by $\mathrm{NaSi}$ is greater than replacement of $\mathrm{Ca}$ by $\mathrm{Na}_{2}$, whereas in $\mathrm{A}$ and $\mathrm{B}$, which have the higher $\mathrm{Na}$ contents, 3.24 and 3.35 atoms per half cell, replacement of $\mathrm{Ca}$ by $\mathrm{Na}_{2}$ is greater than replacement of $\mathrm{CaAl}$ by $\mathrm{NaSi}$. In all four the amount of $\mathrm{NaSi}$ replacement of $\mathrm{CaAl}$ is about the same, $0.62+0.70 \mathrm{CaAl}$ replaced by equivalent amounts of $\mathrm{NaSi}$, but the amount of $\mathrm{Ca}$ replaced by $\mathrm{Na}_{2}$ varies from 0.23 in $\mathrm{D}$ and $\mathrm{C}$, to 0.84 in $\mathrm{A}$ and 0.86 in B. Consequently all four have about the same $\mathrm{Al}$ content and about the same indices of refraction. The relative degree of $\mathrm{NaSi}$ or $\mathrm{Na}_{2}$ replacement is indicated by where the points representing these gonnardites fall with respect to the dual replacement line in figure 3.

The prime (') indices of refraction reported by Mason (1957) for the Norwegian zeolite that he identified as gonnardite are somewhat higher than those reported for analyses $\mathrm{A}, \mathrm{B}, \mathrm{C}$, and $\mathrm{D}$, as its higher $\mathrm{Al}$ content would suggest, 4.95 atoms per half cell. The indices of refraction reported by Hey for the high-Na thomsonites whose points intermingle with those of gon- 
nardite along the dual replacement line in figure 3 are also higher than those for gonnardites $\mathrm{A}, \mathrm{B}, \mathrm{C}$, and D. The high-Na thomsonites are also higher in $\mathrm{Al}$ content than these gonnardites, having relatively less replacement of $\mathrm{CaAl}$ by $\mathrm{NaSi}-$ from 0.24 to 0.46 , compared to 0.62 to 0.70 in $\mathrm{A}, \mathrm{B}, \mathrm{C}$, and $\mathrm{D}$. The indices of refraction for these high-Na thomsonites fall within the ranges of indices for thomsonites. It is probable that further data on the indices of refraction of gonnardite will extend the ranges of the indices of refraction of this zeolite and may show that the ranges of the indices of refraction for gonnardite overlap to some extent those for thomsonite.

The ranges for the indices of refraction of natrolite and mesolite are very narrow, just as their variations in $\mathrm{Al}$ content are very small.

The structural similarities between thomsonite, gonnardite, and natrolite are well known. All three zeolites have framework structures in which every ( $\mathrm{Si}, \mathrm{Al}) \mathrm{O}_{4}$ tetrahedron has each of its oxygens shared with another tetrahedron; linkages to form chains in the $z$ direction are the most prominent. The repeat unit in each chain consists of five tetrahedra and occupies about 6.6A. However, natrolite and thomsonite differ considerably in detail. The structures of thomsonite and natrolite are described by Deer, Howie, and Zussman (1963, p. 361-362) "In thomsonite neighboring chains in the $y$ direction are related by mirror planes (010), but those in the $x$ direction are related by diad axes [010]. The resulting unit cell (orthorhombic Pnma) contains four chains $* * *$. In the structure of natrolite, neighboring chains are related (approximately) by diads only, and this results in a bodycentered cell with dimensions similar to those of thomsonite $(a \approx b \approx 13.1 \AA)$ or a face-centered cell with $a 18.3, b 18.6 \AA * * *$. The difference between $\mathrm{Al}$ and Si tetrahedra and perhaps other deviations from the ideal structure result in orthorhombic (pseudotetragonal) cells for both thomsonite and natrolite. In thomsonite, moreover, such deviations give rise also to a double $c$ parameter $(13.25 \approx 2 \times 6.63)$." The structure of gonnardite is described by Deer, Howie, and Zussman (1963, p. 364) as follows, "Gonnardite has cell parameters similar to those of thomsonite and is assumed to have a similar aluminosilicate framework structure. X-ray fibre photographs of gonnardite are similar to those of thomsonite, and its powder photographs may be confused with those of natrolite (Meixner et al., 1956)." Natrolite is the only one of these three zeolites whose structure has been refined (Meier, 1960).

As the structures of these minerals are similar but differ in detail, it may be that, although analyses suggest a continuous series compositionally, there is a structural change somewhere between thomsonite and natrolite. Such a change would be analogous to the structural change from dioctahedral to trioctahedral which occurs halfway between muscovite and lepidolite, and which breaks the continuity of the compositional series consisting of muscovite, lithian muscovite, and lepidolite (Foster, 1960).

Hey (1932) concluded that the optical properties and $\mathrm{X}$-ray spacings of gonnardite furnish fairly conclusive evidence that it should be regarded as a separate species related to thomsonite perhaps in a manner like that of $\alpha$ - and $\beta$-quartz. He tentatively identified gonnardite with metathomsonite, a high-temperature polymorph of thomsonite. The transition from thomsonite to metathomsonite is reversible and the transition temperature is dependent on the water content. The two forms are compositionally the same, except for water content. On the other hand, gonnardite differs in composition from thomsonite, being intermediate in composition between thomsonite and natrolite, and cannot become thomsonite simply by a decrease in temperature and rehydration as metathomsonite does. To obtain thomsonite from gonnardite requires chemical change.

Hey $\left(1955\right.$, p. 166) gives the $\mathrm{H}_{2} \mathrm{O}$ content of gonnardite as 7 molecules per 20 oxygen atoms. The next year Meixner, Hey, and Moss (1956) give the $\mathrm{H}_{2} \mathrm{O}$ content as 6 molecules per 20 oxygen atoms. It has been noted that in natrolite and mesolite the ratio of $\mathrm{H}_{2} \mathrm{O}$ molecules to $\mathrm{Na}$ ions is $1: 1$, and that in scolecite and mesolite the ratio of $\mathrm{H}_{2} \mathrm{O}$ molecules to $\mathrm{Ca}$ ions is $3: 1$. In thomsonite the ratio of $\mathrm{H}_{2} \mathrm{O}$ molecules to $\mathrm{Na}$ ions is again $1: 1$, but the average ratio of $\mathrm{H}_{2} \mathrm{O}$ molecules to $\mathrm{Ca}$ ions is 2.5:1. Analogously, it would be expected that gonnardites would contain less water than thomsonites, because of the higher $\mathrm{Na}$ content and lower $\mathrm{Ca}$ content. Also, as they are intermediate in chemical composition between thomsonite and natrolite, they would also be expected to be intermediate in $\mathrm{H}_{2} \mathrm{O}$ content. In the analyses of gonnardite given by Meixner, Hey, and Moss, the water content per 20 oxygen atoms varies from 5.35 to 6.1 , molecules. In the analyses given in table 3 , which includes four of the analyses of Meixner, $\mathrm{Hey}$, and Moss, $\mathrm{H}_{2} \mathrm{O}$ varies from 4.85 to 6.46 , and averages 5.54 molecules. The average molecular ratio for $\mathrm{H}_{2} \mathrm{O}$ in the high- $\mathrm{Na}$ thomsonites that fall close to or on the middle line (Nos. 5, 9, 24a, 66, and 69) is 5.42. The average molecular ratio for $\mathrm{H}_{2} \mathrm{O}$ in all the analyses whose $\mathrm{Ca}: \mathrm{Na}$ ratio falls on or close to the dual replacement line in figure 3 is 5.50. For 10 of these 15 analyses the molecular ratio for $\mathrm{H}_{2} \mathrm{O}$ is less than 5.50 , in three it is close to 6.00 , and in two it is more than 6.40. Such $\mathrm{H}_{2} \mathrm{O}$ values tend to support the hypothesis that in zeolites that are intermediate in composition between thomsonite and natrolite the 
content of $\mathrm{H}_{2} \mathrm{O}$ should also be intermediate, and that $\mathrm{H}_{2} \mathrm{O}$ contents of 6.00 or 7.00 , as assumed in formulas for gonnardites, are too high. In this connection it should be taken into consideration that the average given above is based on total $\mathrm{H}_{2} \mathrm{O}$, as only two of the analyses upon which this average is based reported $\mathrm{H}_{2} \mathrm{O}$ - Therefore the true $\mathrm{H}_{2} \mathrm{O}$ content of these zeolites is probably somewhat lower than this average.

\section{FORMULATION}

The formula given by Hey (1955) for gonnardite, 2 $\left[\mathrm{Na}_{2} \mathrm{CaAl}_{4} \mathrm{Si}_{6} \mathrm{O}_{20} \cdot 7 \mathrm{H}_{2} \mathrm{O}\right]$, can be derived from thomsonite only by unilateral replacement of $\mathrm{CaAl}$ by $\mathrm{NaSi}$, as illustrated below:

\footnotetext{
Thomsonite: $\mathrm{Na}_{1.0} \mathrm{Ca}_{2.0} \mathrm{Al}_{5.0} \mathrm{Si}_{5.0} \mathrm{O}_{20} \cdot 6.0 \mathrm{H}_{2} \mathrm{O}$

Faroelite: $\mathrm{Na}_{1.5} \mathrm{Ca}_{1.5} \mathrm{Al}_{4.5} \mathrm{Si}_{5.5} \mathrm{O}_{20} \cdot 6.0 \mathrm{H}_{2} \mathrm{O}$
}

Hey's gonnardite: $\mathrm{Na}_{2.0} \mathrm{Ca}_{1.0} \mathrm{Al}_{4.0} \mathrm{Si}_{6.0} \mathrm{O}_{20} \cdot 7.0 \mathrm{H}_{2} \mathrm{O}$

However, the atomic ratios of all the analyzed gonnardites, as well as the atomic ratios of most of the high Na-thomsonites, indicate dual replacement; replacement of $\mathrm{CaAl}$ by $\mathrm{NaSi}$, and replacement of $\mathrm{Ca}$ by $\mathrm{Na}_{2}$ to about the same degree. Therefore, the formula given by Hey for gonnardite does not reflect the composition of gonnardite as indicated by analyses, nor does it reflect the great variation in composition found in the materials that have been called gonnardites. Nor does the formula usually given for thomsonite reflect the range in composition found in the thomsonites. The usual thomsonite formula is that of the end member, which bears the same relation to thomsonites in general as phlogopite bears to phlogopites in general, and which bears the same relation to gonnardite that phlogopite bears to biotites.

It is obvious that members of a replacement series that vary in composition and that merge into one another cannot be adequately characterized by formulas that indicate fixed relations between the constituents. For members of such a series only formulas that indicate permissible limits of composition are adequate.

The limits of composition with respect to $\mathrm{Na}$ and $\mathrm{Ca}$ between thomsonite and gonnardite and between gonnardite and natrolite suggested herein are selected arbitrarily because the analyses indicate considerable continuity, with no natural breaks along the line joining thomsonite and natrolite (fig. 3). The suggested upper limit for thomsonite is at a dual replacement of $0.20 \mathrm{Ca}+0.20 \mathrm{Al}$ by $0.20 \mathrm{Na}+0.20 \mathrm{Si}$ and of $0.20 \mathrm{Ca}$ by $0.40 \mathrm{Na}$. Starting with theoretical thomsonite, $\mathrm{Na}$ and $\mathrm{Ca}$ at this degree of dual replacement are both 1.60. Up to this degree of dual replacement $\mathrm{Ca}$ is greater than $\mathrm{Na}$, beyond it $\mathrm{Na}$ is greater than $\mathrm{Ca}$. At this degree of replacement of $\mathrm{CaAl}$ by $\mathrm{NaSi}$ the $\mathrm{Al}$ content is 4.80 and the $\mathrm{Si}$ content is 5.20. The upper limit of composition for thomsonite along the line of dual replacement would be, therefore, $\mathrm{Na}_{1.60} \mathrm{Ca}_{1.60} \mathrm{Al}_{4.80} \mathrm{Si}_{5.20} \mathrm{O}_{20} \cdot 5.60 \mathrm{H}_{2} \mathrm{O}$. This composition also represents the lower limit of gonnardite. The suggested upper limit of gonnardite is at a dual replacement of $0.80 \mathrm{Ca}+0.80 \mathrm{Al}$ by $0.80 \mathrm{Na}+0.80 \mathrm{Si}$ and of $0.80 \mathrm{Ca}$ by $1.60 \mathrm{Na}$. This degree of replacement of $\mathrm{CaAl}$ by NaSi results in an $\mathrm{Al}$ value of 4.20 and a $\mathrm{Si}$ value of 5.80. The upper limit of composition for gonnardite would be $\mathrm{Na}_{3.40} \mathrm{Ca}_{.40} \mathrm{Al}_{4,20} \mathrm{Si}_{5.80} \mathrm{O}_{20} \cdot 4.40 . \mathrm{H}_{2} \mathrm{O}$.

The complete formulas with these suggested limits of composition for thomsonite, gonnardite, and natrolite would then be

$$
\begin{aligned}
\text { Thomsonite: } & \mathrm{Na}_{1.0-1.6} \mathrm{Ca}_{2.0-1.0} \mathrm{Al}_{5.0-4.8} \mathrm{Si}_{5.0-5.20} \mathrm{O}_{20} \cdot 6.0-5.6 \mathrm{H}_{2} \mathrm{O} \\
\text { Gonnardite: } & \mathrm{Na}_{1.6-3.4} \mathrm{Ca}_{1.8-0.4} \mathrm{Al}_{4.8-4.2} \mathrm{Si}_{5.2-5.8} \mathrm{O}_{20} \cdot 5.6-4.4 \mathrm{H}_{2} \mathrm{O} \\
\text { Natrolite: } & \mathrm{Na}_{3.4-4.0} \mathrm{Ca}_{0.4-0.0} \mathrm{Al}_{4.2-4.0} \mathrm{Si}_{5.8-6.0} \mathrm{O}_{20} \cdot 4.4-4.0 \mathrm{H}_{2} \mathrm{O}
\end{aligned}
$$

These limits for thomsonite, gonnardite, and natrolite are marked in figure 3 . In these formulas the values for $\mathrm{H}_{2} \mathrm{O}$ are calculated on the basis of a $1: 1$ ratio of $\mathrm{H}_{2} \mathrm{O}$ to $\mathrm{Na}$ and of $2.5: 1$ ratio of $\mathrm{H}_{2} \mathrm{O}$ to $\mathrm{Ca}$, as in thomsonite.

In accordance with these range formulas, analysis No. 24a, table 2, with $1.58 \mathrm{Na}$ and $1.59 \mathrm{Ca}$ comes just within the upper limits for thomsonite, and in 69 , table $2, \mathrm{Ca}$ is just within the lower limits for gonnardite. No. 1, table 1, falls well within the limits for thomsonite. No. 9, table 1, and Nos. 28 and 66, table 2, and all the analyses given in table 3 fall within the gonnardite range.

It must be understood that the range formula given above for thomsonite applies only to thomsonites belonging to this dual replacement series. Thomsonite in the $\mathrm{NaSi} \rightarrow \mathrm{CaAl}$ line of replacement would have a range formula reflecting the atomic relations in this line of replacement, such as

$$
\mathrm{Ca}_{2.0-1.5} \mathrm{Na}_{1.0-1.5} \mathrm{Al}_{5.0-4.5} \mathrm{Si}_{5.0-5.5} \mathrm{O}_{20} \cdot 6.0-5.25 \mathrm{H}_{2} \mathrm{O} \text {, }
$$

which embraces faroelite.

\section{OTHER LINES OF REPLACEMENT}

In addition to the two lines of replacement that have been discussed, four other possible lines of replacement are indicated in figure 3 . One of these, like the two that have been discussed, is a $\mathrm{Ca}$ replacement line, replacement of $\mathrm{Ca}$ by $\mathrm{Na}_{2}$. The other three are all $\mathrm{Na}$ replacement lines, continuations of the three $\mathrm{Ca}$ replacement lines. However, except for a few points that fall close to theoretical thomsonite, none of the points representing the $\mathrm{Ca} / \mathrm{Na}$ relations of analyses whose atomic ratios are given in tables 1 and 2 fall along these lines. Replacement of $\mathrm{Na}$ by $\mathrm{Ca}$ in thomsonites appears to be quite subordinate to replacement of $\mathrm{Ca}$ by $\mathrm{Na}$, and replacement of $\mathrm{Ca}$ by $\mathrm{Na}_{2}$ seems to be found most commonly in conjunction with replacement of $\mathrm{Ca}$ as $\mathrm{CaAl}$ by $\mathrm{NaSi}$, as along the dual replacement line. 


\section{CONCLUSION}

This study has shown that gonnardites, and several high-Na mesolites, and certain thomsonites that are characterized by dual $\mathrm{NaSi} \rightarrow \mathrm{CaAl}$ and $\mathrm{Na}_{2} \rightarrow \mathrm{Ca}$ replacements, are all intermediate in composition between thomsonite and natrolite, and suggest an isomorphous series between them. However, differences in optical properties and in structure cast doubt on such an interpretation. Whether all these zeolites are members of an isomorphous series between thomsonite and natrolite or whether only the high-Na thomsonites belong to such a series, and the gonnardites and high-Na mesolites are polymorphic forms, are problems that require more data, especially on their structures, and more study for their clarification.

\section{REFERENCES}

Antonin, Rudolf, 1942, Research on the minerals and rocks of Vinařická hill: Královské České Společnosti Nauk Věstník, art. 2, $19 \mathrm{p}$.

Deer, W. A., Howie, R. A., and Zussman, Jack, 1963, Rock forming minerals. v. 4, Framework silicates: New York, John Wiley \& Sons, Inc., 435 p.

Deriu, Michele, 1954, Mesolite di Rio Cambone (MontiferroSardegna centro-occidente): Periodico Mineralog. Roma, v. 23, p. $37-47$.
Foster, Margaret D., 1960, Interpretation of the composition of lithium micas: U.S. Geol. Survey Prof. Paper 354-E, p. 122-127.

Hey, Max H., 1932, Studies on the zeolites. Part II. Thomsonite (including faroelite) and gonnardite: Mineralog. Mag. v. 23 , p. 51-125.

- - 1955, An index of mineral species and varieties arranged chemically, 2d ed.: London, British Museum (Natural History), $728 \mathrm{p}$.

Kostov, Ivan, 1958, Zeolites in Bulgaria: scolecite, mesolite, "gonnardite," and thomsonite: Sofia Univ. Biolog-GeologGeograph. Fakultet, Godishnik, v. 53, p. 1-24.

Mason, Brian, 1957, Gonnardite (ranite) from Langesundsfjord: Norsk Geol. Tidsskr., v. 37, p. 435-437.

Meier, W. M., 1960, The crystal structure of natrolite: Zeitschr. Kristallographie, v. 113, p. 430-444.

Meixner, Heinz, Hey, M. H., and Moss, A. A., 1956, Some new occurrences of gonnardite: Mineralog. Mag. v. 31, p. 265271.

Paykull [Paijkull], S. R., 1874, Rauit, ein neues Mineral von Brewig: Deutsch. Chem. Gesell. Berlin, Ber., v. 7, pt. 2, p. 1334-1335.

Taylor, W. H., Meek, C. A., and Jackson, W. W., 1933, The structure of the fibrous zeolites: Zeitschr. Kristallographie, v. 84 , p. $373-398$.

Winchell, A. N., 1925, A new theory of the composition of the zeolites: Am. Mineralogist, v. 10, 88-97. - 1926, Doubtful mineral species as illustrated by "faroelite": Am. Mineralogist, v. 11, p. 82-89. 